Future Realized Return, Firm-Specific Risk and the Implied Expected Return

\author{
Pengguo Wang ${ }^{1}$ \\ Xfi Centre for Finance and Investment \\ Exeter University Business School \\ Exeter EX4 4ST, UK \\ p.wang@exeter.ac.uk
}

\footnotetext{
${ }^{1}$ I thank David Ashton, Mark Clatworthy, Daniela Acker, Alan Gregory, Mike Jones, Stuart McLeay (EAA discussant), Peter Pope, Mark Tippett and seminar participants at University of Birmingham, University of Bristol, Warwick University, University of Swansea, Nottingham University (Ningbo), Beijing University, Wuhan University, Fuzhou University and EAA2014 for helpful comments and suggestions. I would like to express my thanks to an anonymous referee as well as the editor Stewart Jones and associate editor David Johnstone for their helpful comments. Finally, I am gratefully acknowledge the financial support of the Economic and Social Research council under award \# ES/J023914/1.
} 


\title{
Future Realized Return, Firm-Specific Risk and the Implied Expected Return
}

\begin{abstract}
In this paper, we propose a novel approach to derive a firm-specific measure of expected return. It builds on recent accounting-based valuation models developed by Clubb (2013) and Ashton and Wang (2013). The measure is intrinsically linked to commonly used financial ratios including book-to-market, (forward) earnings yield, dividend-to-price as well as growth and past returns. The empirical evidence shows that it is significantly positively associated with future realized stock returns and also significantly correlates with commonly used risk characteristics in a theoretically predictable manner. The results are likely to be of interest to practitioners and managers in making capital allocation decisions and to academics in need of proxies for firms' discount rates and expected returns.
\end{abstract}

Keywords: Implied risk premium; Firm risk characteristics; Earnings forecasts JEL: G12, G32, M41 


\section{Future Realized Return, Firm-Specific Risk and the Implied Expected Return}

\section{Introduction}

A growing number of studies in finance and accounting employ the implied cost of equity capital or the internal rate of return as a proxy for expected stock returns. ${ }^{2}$ However, the proxy often fails to reliably predict future stock returns (Pastor et al. (2008)). Moreover, the crosssectional relationship between the proxy and firm-specific risk characteristics is inconclusive (Botosan and Plumlee (2005)). ${ }^{3}$ In this paper, we develop a novel approach to estimate expected one-period ahead stock returns by projecting future returns onto a set of accounting fundamentals and market variables embedded in recent accounting-based valuation models. We show that our proxy for expected stock returns is significantly positively associated with future realized stock returns and also significantly correlates with commonly used risk characteristics in a theoretically predictable manner.

By extending Clubb (2013) and Ashton and Wang (2013), we demonstrate that firm-specific one-period ahead returns are intrinsically linked to the commonly used financial ratios including book-to-market, (forward) earnings yield, dividend-to-price, as well as growth and past returns. Since the linkage is built on the established accounting-based valuation models, expected one-period ahead return is labeled as the implied expected return (IER). Our expression identifies firm characteristics that are associated with risky future growth as explaining the IER. It provides an explanation for why book-to-market $(\mathrm{B} / \mathrm{P})$ may be useful for

\footnotetext{
${ }^{2}$ Pastor et al. (2008) apply the implied cost of equity capital (ICC) approach to test the Intertemporal CAPM, while Lee et al. (2009) use the ICC to test international asset pricing models. The ICC methodology has been used to examine whether cross-listing reduces foreign firms' cost of capital and the effectiveness of a country's legal institutions and securities regulation (Hail and Leuz (2006, 2009)). The ICC approach has also been employed to investigate default risk (Chava and Purnanadam (2009)) and executive pay disparity (Chen et al. (2013)).

${ }^{3}$ The correlations between many expected return proxies and realized returns are often not statistically different from zero. Some studies find a positive relation between the ICC and market beta (Kaplan and Ruback (1995), Gode and Mohanram (2003)), and some find a negative relation (Hou et al. (2012)), while others find this relation to be mostly insignificant (Gebhardt et al. (2001), Lee et al. (2009)).
} 
explaining expected stock returns. ${ }^{4}$ It shows that neither should book-to-market be viewed as a risk factor, nor does market-to-book $(\mathrm{P} / \mathrm{B})$ itself represent growth as commonly interpreted. However, B/P interacts with the growth of future investments, so investors may rationally take it into account in pricing equity shares. It also shows that the IER is associated with forward earnings yield that is related to uncertainty about future earnings. This is consistent with Penman and Zhu (2014) and Penman (2016), who express expected returns in terms of expectations of earnings and earnings growth. ${ }^{5}$ Furthermore, it shows that accounting conservatism can cause time-serial correlation in stock returns.

The coefficients of the financial ratios in the IER expression are functions of five valuation parameters including expected long term growth of the NPV of future investments and long term cost of capital based on currently available information. Following Ashton and Wang (2013), we use one-year ahead forecasts of earnings and estimate simultaneously the five valuation parameters according to a long-standing industry practice of using benchmark industry averages in the valuation of an individual firm (Damodaran (2002), Liu et al. (2002), Penman (2010)). ${ }^{6}$

The existing literature evaluates the usefulness of a proxy for expected stock return mainly by testing whether it can predict realized returns. We show that the implied expected return is significantly positively associated with future realized stock returns for a sample of $\mathrm{I} / \mathrm{B} / \mathrm{E} / \mathrm{S}$ U.S. firms over the period 1980-2011. The measure remains significantly positively related to

\footnotetext{
${ }^{4}$ Liew and Vassalou (2000) find that book-to-market and size portfolios are related to future growth in the real economy. Book-to-market has been explained as growth options (Berk et al. (1999)) and investment and asset growth (Cooper et al. (2008)). Vassalou (2003) argues that news related to future GDP growth can explain the cross-section of equity returns as well as the Fama-French model can.

${ }^{5}$ Penman and Zhu (2014) document that variables that forecasts earnings and earnings growth also forecasts expected returns. Penman et al. (2014) also identify forward earnings yield as an omitted factor from a characteristic model. However, in contrast to our model, the expression in Penman et al. is a tautology (Penman (2016, p.110)). The return decomposition developed by Easton and Monahan (2005) is also based on two tautologies (Easton and Monahan (2016 p.45)).

${ }^{6}$ The main advantages of Ashton and Wang (2013) method are that it does not explicitly assume dividend payout policy and requires only one-year-ahead forecasts of earnings. However, it only allows one to estimate the average implied cost of capital and growth rate for a given portfolio of firms.
} 
future realized stock returns, even after controlling for commonly used risk proxies (the CAPM beta, size and leverage) and cash flow and discount rate news (Campbell (1991), Vuolteenaho (2002)), as well as term spread and default spread (Fama and French (1989)). We also document the IER's out-of-sample predictive ability with respect to future stock returns by sorting firms into quintiles of IER distribution each year. For each portfolio, the mean buyand-hold returns for the next 12- and 60-month are calculated. We find that the IER measure exhibits a monotonic relation with future realized returns. Hedge return, the difference in the cumulative 60-month realized returns between the top and bottom quintiles of the IER, is equal to $46.6 \%$. Prior literature that assesses the validity or reliability of firm-specific estimates of expected return has also been motivated on correlations with commonly used risk proxies. In this respect, our measure is associated with conventional risk characteristics in a theoretically predictable manner. Specifically, it shows a significant positive relation between expected risk premium and market beta, leverage, default spread, and negative association between implied risk premium and firm size.

The rest of the paper is organized as follows. Section 2 introduces an accounting-based valuation model and discusses the intrinsic relationship between the implied one-period ahead return and various fundamental characteristics of a firm. Section 3 describes the sample and empirical implementation in estimating of the implied expected return. Section 4 provides the estimation results and assesses the validity of the estimates. Section 5 concludes.

\section{The Implied One-Period Ahead Return and Firm Characteristics}

Assuming information dynamics on abnormal earnings, book values, dividends, the noarbitrage condition and clean surplus accounting, Clubb (2013) extends the Ohlson (1995) framework and shows that price of equity $\left(P_{t}\right)$ can be written in terms of book value $\left(b_{t}\right)$, 
dividend $\left(d_{t}\right)$, and abnormal earnings $\left(x_{t}^{a}\right)$ as ${ }^{7}: P_{t}=\left(1+\beta_{1}\right) b_{t}+\beta_{1} d_{t}+\beta_{2} x_{t}^{a}$, where $x_{t}^{a}=x_{t}-(R-1) b_{t-1}, x_{t}$ is earnings, $R$ is one plus the long term average cost of equity capital based on time $t$ information. While this expression demonstrates that dividends displace both book value and market value on a dollar-for-dollar basis, it does not consider explicitly the present value of all future investments. In related research, Ashton and Wang (2013) introduce a growth variable that describes the net present value of all future investments $\left(\vartheta_{t}\right)$. Naturally, we merge these two models as below:

$$
\begin{aligned}
& P_{t}=\left(1+\beta_{1}\right) b_{t}+\beta_{1} d_{t}+\beta_{2} x_{t}^{a}+\vartheta_{t} \\
& \vartheta_{t+1}=(1+g) \vartheta_{t}+\lambda\left(P_{t}+d_{t}-P_{t-1}-x_{t}\right)+\varepsilon_{t+1}
\end{aligned}
$$

where $g(<R-1)$ is the long term average growth rate of the net present value of future ex ante investments based on time $t$ information. The second term on the right hand side of equation (2) adjusts for the potential impact of accounting conservatism since conservatism in reporting may influence beliefs about future profitability when the expectation of growth is formed. ${ }^{8}$ Here $\lambda$ is labeled as a conservatism parameter and conservatism is measured by the difference between economic earnings, $\left(P_{t}-P_{t-1}+d_{t}\right)$, and accounting earnings. Valuation multiples satisfy $\beta_{1} \geq(R-1) \beta_{2}>0 .{ }^{9} \varepsilon_{t+1}$ is an error term with mean zero.

\footnotetext{
${ }^{7}$ This model is also consistent with Collins et al. (1999) and Pope and Wang (2005).

${ }^{8}$ Claus and Thomas (2001) argue that expected growth is affected by both the expectation of future economic rents and the conservative nature of accounting. Conservative accounting implies 'something about the future payoff' (Johnstone (2016, p.2)).

${ }^{9}$ Note that equation (1) can be rewritten as $P_{t}=\left[1+\beta_{1}-(R-1) \beta_{2}\right] b_{t}+\left[\beta_{1}-(R-1) \beta_{2}\right] d_{t}+R \beta_{2} x_{t}+\vartheta_{t}$. Equity value is expected to increase in the firm's (abnormal) earnings in general $\left(\beta_{2}>0\right)$. For a majority of firms book values are understated under conservative accounting. For example, physical assets are recorded at historical costs; inflation and associated asset holding gains are ignored; R\&D is sometimes viewed as an expense rather than an investment; and many intangible assets are not recognized. We would expect the coefficient of book value is greater than 1 , or $\beta_{1} \geq(R-1) \beta_{2}>0$.
} 
Assuming the clean surplus accounting (i.e., $b_{t+1}+d_{t+1}=x_{t+1}+b_{t}$ ), equations (1) and (2) imply the one-period ahead total return:

$$
\frac{P_{t+1}+d_{t+1}}{P_{t}}=\left[1+\beta_{1}-(R-1) \beta_{2}\right] \frac{b_{t}}{P_{t}}+\left[1+\beta_{1}+\beta_{2}\right] \frac{x_{t+1}}{P_{t}}+\frac{\vartheta_{t+1}}{P_{t}}
$$

All proofs can be found in the appendix. The positive association between book-to-market ratio $(\mathrm{B} / \mathrm{P})$ and equity return becomes apparent when we control for forward earnings yield and ratio of one-period ahead NPV of future investments to price. When regressing expected return on book-to-market, and either reasonable proxies for $\frac{E_{t}\left[\vartheta_{t+1}\right]}{P_{t}}$ and $\frac{E_{t}\left[e_{t+1}\right]}{P_{t}}$, or both forward ratios are missing, one would observe that $\mathrm{B} / \mathrm{P}$ is positively related to expected returns. This is consistent with findings in Fama and French $(1988,1992,1993,2006)$ and others.

In parallel with the standard dividend growth model, equation (3) can be written in terms of growth, dividend yield, abnormal growth in book value and abnormal growth in forward earnings as:

$$
\begin{aligned}
\frac{P_{t+1}+d_{t+1}}{P_{t}} & =1+g+(1+g) \frac{d_{t}}{P_{t}}+\left(1+\beta_{1}-(R-1) \beta_{2}\right) \frac{b_{t}-(1+g) b_{t-1}}{P_{t}} \\
& +\left(1+\beta_{1}+\beta_{2}\right) \frac{x_{t+1}-(1+g) x_{t}}{P_{t}}+\lambda\left[\frac{\left(P_{t}+d_{t}-P_{t-1}\right)-x_{t}}{P_{t}}\right]+\frac{\varepsilon_{t+1}}{P_{t}} .
\end{aligned}
$$

It is clear that equity returns and growth are interlinked (Penman (2016)). In particular, if we set $\beta_{1}=\beta_{2}=0$, and $\lambda=0$, equation (4) reduces to

$$
\frac{P_{t+1}+d_{t+1}}{P_{t}}-1=g+\frac{x_{t+1}}{P_{t}}-g \frac{b_{t}}{P_{t}}+\frac{\varepsilon_{t+1}}{P_{t}}
$$

Equation (5) shows that $\mathrm{B} / \mathrm{P}$ is negatively related to the one-period ahead return and $\mathrm{B} / \mathrm{P}$ amplifies the growth after controlling for growth and forward earnings yield. ${ }^{10}$ This is in

\footnotetext{
${ }^{10}$ Ohlson (2005) derives the same model from a different starting point and argues that risk ought to decrease as
} 
contrast to a large body of empirical asset pricing literature. If there is no growth $(\mathrm{g}=0)$, then B/P should not have explanatory power to expected returns. This parsimonious model suggests that neither should book-to-market be viewed as a risk factor, nor does market-to-book (P/B) itself represent growth as commonly interpreted. Although the forward earnings yield has long been used in equity valuation by financial analysts, it appears until recently that not enough attention has been paid to forward earnings in the empirical asset pricing literature (Fame and French (2006), Lyle et al. (2013), Penman (2016)).

It is also interesting to note that equation (4) provides an alternative explanation as to why current returns may be associated with future returns. It shows that accounting conservatism can cause time-serial correlation in stock returns. Accounting conservatism understates 'true' current incomes, or only recognizes a portion of economic earnings. The unrecognized portion will be recognized at a later stage and may be reflected in future returns. ${ }^{11}$ The conservative nature of reporting may influence investors' beliefs about future profitability when expectations of growth and future earnings are formed.

Since dividends in equation (4) are dividends net of new capital contributions, for our purpose we replace dividends by lagged book value via the clean surplus accounting, $d_{t}=x_{t}+b_{t-1}-b_{t}$. It follows from (4) that ${ }^{12}$

$$
\begin{aligned}
\frac{P_{t+1}+d_{t+1}}{P_{t}}= & (1+g)\left[1-\frac{b_{t}}{P_{t}}-\left(\beta_{1}-(R-1) \beta_{2}\right) \frac{b_{t-1}}{P_{t}}-\left(\beta_{1}+\beta_{2}\right) \frac{x_{t}}{P_{t}}\right]+\left(1+\beta_{1}-(R-1) \beta_{2}\right) \frac{b_{t}}{P_{t}} \\
& +\left(1+\beta_{1}+\beta_{2}\right) \frac{x_{t+1}}{P_{t}}+\lambda\left[\frac{\left(P_{t}+d_{t}-P_{t-1}\right)-x_{t}}{P_{t}}\right]+\frac{\varepsilon_{t+1}}{P_{t}} .
\end{aligned}
$$

the $\mathrm{B} / \mathrm{P}$ increases for a fixed earnings yield.

${ }^{11}$ If an asset is over depreciated, for instance, then it will be under depreciated at some future date as there exists a reversing process.

12 This expression shows explicitly what 'added accounting variables' in the return model in Penman and Zhu (2014) should be consided. 
Therefore, the implied one-period ahead equity returns are intrinsically linked to the commonly used financial ratios including book-to-market and (forward) earnings yield, as well as growth and past returns. ${ }^{13}$

In order to estimate the expected one-period ahead return based on equation (6), we need to estimate valuation parameters $\left(\beta_{1}, \beta_{2}, \lambda, R, g\right)$, for given firm-specific information or accounting ratios and forecasted one-period ahead earnings. While an individual firm's valuation parameters in equations (1) and (2) may be estimated according to a long-standing industry practice of using benchmark industry averages (Damodaran (2002), Liu et al. (2002), Penman (2010)), it is still a challenge to estimate simultaneously $R$ and $g$. The terminal growth rate used to truncate infinite future cash flows in a valuation model is often assumed by researchers. ${ }^{14}$ Fortunately, recent advances in the implied cost of capital literature provide us with techniques to estimate simultaneously all valuation parameters including $R$ and $g$ for a given portfolio of firms. ${ }^{15}$ Therefore, we do not have to assume the same growth rate for all firms as in the existing implied cost of capital literature. Instead, we differentiate growth rates across portfolios (industries) to distinguish different growth opportunities and different risk (Penman (2016)). The approach developed in Ashton and Wang (2013) among others has some other notable advantages in terms of information requirements since it does not explicitly assume dividend payout policy and requires only one-period ahead forecasts of earnings. ${ }^{16}$

\footnotetext{
${ }^{13}$ This is also consistent with Lyle et al. (2013) and Callen (2016), who show that expected return can be written in terms of book-to-price, (forward) earnings-to-price and dividend-to-price when abnormal earnings dynamic follows a mean-reverting process. Recently, Christodoulou et al. (2016) also show that the ICC can be estimated using only reported accounting information and without reference to stock price.

${ }^{14}$ For example, Claus and Thomas (2001) assume that residual incomes grow at the same rate (i.e. an estimate of the expected inflation rate) across all firms. Dargenidou et al.(2006) also use the government bond yield (the risk free rate ) as a proxy for long term growth.

${ }^{15}$ Penman argues that 'the joint estimation of ER (the implied cost of capital) and $g$ in Easton et al. (2002) as if they were independent inputs to a valuation is suspect if growth is risk'(Penman (2016, p.119)). Equation (11) in the appendix shows that estimating the implied cost of capital and growth rate simultaneously does not mean that they are independent inputs. One can first estimate $g$, then the implied cost of capital as a function of $g$ and other parameters.

${ }^{16}$ Dividend payout policy is usually supposed over a forecast period, and multiperiod forecasts of earnings or price targets are normally required in the existing literature. For instance, Gebhardt et al. (2001) rely on up to
} 
The key step to the Ashton and Wang approach is to express the expected one-period ahead earnings in terms of accounting fundamentals and stock prices. In our model setup, equations (1) and (2), together with the no-arbitrage condition and clean surplus accounting imply that the expected one-period ahead earnings can be written as:

$$
\begin{aligned}
E_{t}\left[x_{t+1}\right] & =\frac{R-(1+g)-\lambda}{\left(1+\beta_{1}+\beta_{2}\right)} P_{t}+\frac{(1+g)\left(\beta_{1}+\beta_{2}\right)}{\left(1+\beta_{1}+\beta_{2}\right)} x_{t}+\frac{g-\beta_{1}+(R-1) \beta_{2}+\lambda}{\left(1+\beta_{1}+\beta_{2}\right)} b_{t} \\
& +\frac{(1+g)\left(\beta_{1}-(R-1) \beta_{2}\right)-\lambda}{\left(1+\beta_{1}+\beta_{2}\right)} b_{t-1}+\frac{\lambda}{\left(1+\beta_{1}+\beta_{2}\right)} P_{t-1} .
\end{aligned}
$$

Given a proxy of expected earnings, cross-sectional regressions will give the estimates for coefficients attached to price, earnings and book value in equation (7). From the corresponding five coefficients, we can estimate simultaneously the implied cost of equity capital $(R-1)$, growth rate $(\mathrm{g})$ and valuation parameters, $\beta_{1}, \beta_{2}$ and $\lambda$, for a given portfolio of firms, or an industry.

\section{Describing Sample and Empirical Implementation}

\subsection{Sample Description}

The sample includes all NYSE, Amex and Nasdaq listed securities. Data are extracted from the CRSP monthly returns file from January 1975 to June 2011, and the Compustat industrial annual file from 1978 to 2010 and forecasts of earnings from the Institutional Brokers Estimate System (I/B/E/S) between 1979 and 2010. The adjusted number of shares outstanding and adjusted price at the end of the fiscal year, and adjusted price of equity three months after the fiscal year-end are collected from CRSP. ${ }^{17}$ Stock price three months after the fiscal year-end is

three years of earnings forecasts and assume that firms have a $100 \%$ dividend payout ratio beyond the forecast horizon. Claus and Thomas (2001) assume that 50\% of earnings are retained each period. Easton et al. (2002) are based on up to four years of earnings forecasts and assume that the expected dividends in the subsequent four years are equal to the current dividends paid.

17 The cumulated adjustment factors for number of share and for stock price are collected from CRSP to 
used to ensure that information about the prior year financials has been incorporated in the analysts' forecasts of earnings. Accordingly, 12-month buy-and-hold returns for each firm from April to March each year are calculated. ${ }^{18}$ This is also consistent with the fact that a majority of firms have fiscal year end in December. ${ }^{19}$ Relevant accounting data are collected from Compustat. Firms with negative book values (CEQ) are deleted. Earnings are measured as net income before extraordinary items (IB). The median consensus forecasts of earnings per share at the first month after the corresponding $\mathrm{I} / \mathrm{B} / \mathrm{E} / \mathrm{S}$-reported prior-year earnings announcements are used. All total variables used in the estimation are divided by the adjusted number of shares outstanding to reduce heteroskedasticity and increase comparability across time. Size is measured as the logarithm of a firm's market capitalization, leverage as the total debt divided by the firm's market capitalization as of 3-months after the fiscal year end. Total debt is the sum of long-term debt (DLTT) and short-term debt (DLC). Market beta is estimated via the market model using the value weighted NYSE/Amex market index return using at least 18 and up to 60 months of lagged monthly returns. The standard deviations of monthly returns are also computed using at least 18 months of data over the prior 60 months as a measure of total risk.

In constructing the data set in this analysis, $1 \%$ at the top and bottom of book value, earnings, stock price, number of shares outstanding, and analysts' consensus forecasts of earnings are deleted to avoid the influence of extreme observations.

\section{<Insert Table 1 about here>}

Table 1, Panel A presents the descriptive statistics of the sample firms and analysts' consensus forecasts of earnings. We observe that the median of analysts' forecasts is about $28 \%$ higher

\footnotetext{
calculate the adjusted number of shares outstanding and the adjusted price.

18 This is in contrast with returns calculated from July to June in Fama and French $(1992,1993,1995)$ and others. Company financials become public information much more quickly compared with two decades ago due to technological advances. In addition, companies are now required by law to publish their accounts in 2-3 months after their fiscal year-end.

${ }^{19}$ The main results are not altered when the analysis is done for December fiscal year-end firms only.
} 
than that of actual reported earnings, reflecting the over-optimism of analysts' forecasts. While the mean (median) book-to-market is about $0.84(0.56)$, the mean of earnings-to-price and the mean of one-year ahead forward earnings-to-price are $4.8 \%$ and $6.7 \%$ respectively.

Table 1, Panel B shows the annual cross-sectional correlations for 60,170 observations over the 31 year period from 1980 to 2010. The upper (lower) right triangle of the matrix presents Spearman (Pearson) correlations. These correlations show that contemporary price and current earnings are the variables with the largest correlation coefficients with forecasts of earnings.

\subsection{Empirical Implementation}

Based on equation (7), the analysis needs only one-year ahead expected earnings and other contemporary variables. We use one-year ahead analysts' forecasts of earnings as a proxy of expected earnings. Given the one-year ahead forecasts of earnings $\left(x_{t+1}\right)$ for all the firms within a given portfolio or grouping of firms, we can run the following cross-sectional regressions for all firms within the portfolio in each year:

$$
x_{t+1}=\delta_{1} P_{t}+\delta_{2} x_{t}+\delta_{3} b_{t}+\delta_{4} b_{t-1}+\delta_{5} P_{t-1}+\varepsilon_{x, t+1},
$$

where $\varepsilon_{e, t+1}$ is an error term. Therefore the sample long term average growth rate $(g)$, cost of capital $(R)$, valuation multiples $\left(\beta_{1}\right.$ and $\beta_{2}$ ) and conservatism parameter $(\lambda)$ can all be written in terms of regression coefficients $\delta_{1}-\delta_{5}$ applicable to firms within that portfolio as in equations (10)-(12) in the Appendix.

Consistent with industry practice, we use the sample average growth rate, cost of capital and valuation multiples as common parameters for all firms in each industry-year portfolio to obtain 
the firm-specific one-period ahead return. ${ }^{20}$ Therefore, the firm-specific implied expected oneperiod return $I E R_{t} \equiv \frac{E_{t}\left[P_{t+1}+d_{t+1}-P_{t}\right]}{P_{t}}$ at time $t$ can be estimated from equation (6) as

$$
\begin{aligned}
I E R_{t}= & \left(1+\bar{g}_{i t}\right)\left[1-\frac{b_{t}}{P_{t}}-\left(\bar{\beta}_{1, i t}-\left(\bar{R}_{i t}-1\right) \bar{\beta}_{2, i t}\right) \frac{b_{t-1}}{P_{t}}-\left(\bar{\beta}_{1, i t}+\bar{\beta}_{2, i t}\right) \frac{x_{t}}{P_{t}}\right]+\left(1+\bar{\beta}_{1, i t}+\bar{\beta}_{2, i t}\right) \frac{E_{t}\left[x_{t+1}\right]}{P_{t}} \\
& +\left(1+\bar{\beta}_{1, i t}-\left(\bar{R}_{i t}-1\right) \bar{\beta}_{2, i t}\right) \frac{b_{t}}{P_{t}}+\bar{\lambda}_{i t}\left[\frac{P_{t}-b_{t}-\left(P_{t-1}-b_{t-1}\right)}{P_{t}}\right]-1,
\end{aligned}
$$

where $\bar{R}_{i t}, \bar{g}_{i t}, \bar{\alpha}_{1, i t}, \bar{\alpha}_{2, i t}$ and $\bar{\lambda}_{i, t}$ are long term average cost of capital, growth rate, valuation multiples and conservatism parameter respectively for firms in industry $i$ and year $t$.

In summary, the analysis has two steps. The first step is to estimate the sample average of cost of capital, growth rate and valuation multiples based on equations (8), and (10)-(12) on an industry-year basis. The second step is to compute the firm-specific expected one-year ahead return based on equation (9). In the following analysis, the 10-year US government bond yield is subtracted from the IER to compute the implied risk premium. This implied risk premium is the measure of the expected risk premium (ERP) that is used in the following regression tests.

To examine the (incremental) explanatory power of the implied expected return (IER) on future realized returns, the relationship between one-year ahead excess realized stock returns (i.e. oneyear ahead realized returns subtracted by the 10-year US government bond yield, XRET1) on the ERP and other control variables is tested. These control variables include the unexpected return due to cash flow news, discount rate news and conventional risk characteristics: the CAPM beta, book-to-market, firm size, leverage, term spread and default spread. A positive correlation between the ERP and XRET1 provides support for the validity of the IER. A valid

\footnotetext{
${ }^{20}$ For the purpose of this paper, we estimate the unknown $\mathrm{g}$ at the industry-year level and plug it into the model with firm-specific variables to obtain the firm-specific implied cost of capital. One could well have used a constant implied cost of capital and other coefficients at the industry-year level and estimated a firm-specific $g$ if one's objective is to estimate firm-specific growth.
} 
proxy of expected return should also be consistent with established asset pricing theory (for example, Lintner (1965), Sharpe (1964), Modigliani and Miller (1958)). Although the true risk factors that determine expected returns are unknown or they may not be reliably estimated, as a first order approximation we can examine the relationship between the expected risk premium (ERP) and a few well-known risk proxies, such as market beta, leverage, default risk, and the market value of equity (size).

\section{Empirical Results}

\subsection{Average cost of capital, growth rate and valuation multiples for the industry-year portfolios}

We first divide the full sample into 5 industries using the classification from Ken French's website. To increase the observations for each of the 150 portfolios in an industry-year analysis, a two-year rolling window for 30-year over 1980-2009 is used..$^{21}$ To reduce nonstationarity and minimize the effects of endogeneity, both sides of equation (8) are deflated by the price three months after the fiscal year-end to provide contemporaneity with the fiscal year-end reporting of book values and earnings. The analysts' forecasts of one-year ahead earnings per share are used as the dependent variable.

<Insert Table 2 about here>

Table 2 reports the parameter estimates in the regression for each of 150 industry-year portfolios. Panel A shows the average of estimates for all 5-industries on a year-by-year basis.

\footnotetext{
${ }^{21}$ For example, for year 1980, forecasts of earnings for 1980 and 1981 and accounting data for 1979 and 1980 are used. If industry classification is per Fama-French (1997), it needs more years rolling window to have sufficient observations for firms in some of the 48-industry each year. Consequently, the number of portfolios will increase to $48 \times 30=1440$.
} 
The sample size varies over the 30 years from a low of 1,682 firms in 1980 to a high of 4859 firms in 2006 over a two-year window. The average number of annual observations is 3,545. All of the $\delta_{1} \mathrm{~s}$ and $\delta_{2} \mathrm{~s}$ are positive as predicted. We observe that $\delta_{1}$ and $\delta_{5}$ are highly significant with regard to explaining one-year ahead earnings, confirming that prices lead earnings after controlling for current earnings and book values. We also note that current earnings $\left(\delta_{2}\right)$ are an important predictor of future earnings. Neither the coefficient of current book value $\left(\delta_{3}\right)$ nor the coefficient of lagged book value $\left(\delta_{4}\right)$ is statistically significant. ${ }^{22}$ Panel B shows the average of estimates for 30 years on an industry-by-industry basis. The results are consistent with Panel A. They confirm that prices lead earnings and that earnings are highly persistent. On average, five variables: current earnings, current and lagged prices, and current and lagged book values, together explain $38.6 \%$ of one-year ahead of analysts' forecasts of earnings.

\section{<Insert Table 3 about here>}

Table 3 details the estimates of long term average cost of capital, growth rates, valuation multiples, accounting conservatism parameter, and risk premia for the 150 industry-year portfolios. Similar to Table 2, results on a year-by-year basis (Panel A) and on an industry-byindustry basis (Panel B) are reported. We observe that the annual mean cost of capital is $9.6 \%$ and the mean risk premium is $2.32 \%$ over $1980-2009$. Risk premium is based on ten-year U.S. government bond yields as a proxy for the risk-free rate. Our estimate of the annual mean growth rate is $3.34 \%$. We also note a downward trend in the cost of capital, with the average falling from $12 \%$ between $1980-1990$ to $9.66 \%$ between $1991-2000$, and finally to $6.48 \%$ between 2001-2009. While the average long-run growth is $3.95 \%$ between $1980-2003$, the annual growth rate is not statistically different from zero after 2004. However, as shown in

\footnotetext{
${ }^{22}$ It may suggest that analysts do not pay much attention on book value when they forecast net earnings.
} 
Figure 1, the risk premium shows an upward trend between 2004-2009, reflecting the fact that the risk-free rate decreases at a greater rate than the mean IER. This coincides with the recent financial and credit crisis, and investors demanding a higher risk premium. As expected, all valuation weight on book value $\left(1+\beta_{1}\right)$ is greater than 1 over the 30 -year period. All valuation weights on earnings $\left(\beta_{2}\right)$ are greater than zero and statistically significant at the $1 \%$ level. The conservatism parameters $(\lambda)$ is always positive, with a mean value of 0.017 . The FamaMacBeth t-statistics for all five valuation parameters are statistically significant at the $1 \%$ level.

<Insert Figure 1 about here>

Figure 1 illustrates the trend in cost of capital, the risk premium and long-run growth. Results on an industry-by-industry basis shown in Panel B are similar.

\subsection{Firm-specific IER and its relation with realized returns and risk proxies}

Applying the parameters estimated in the above analysis to each firm in the 150 industry-year portfolios, to equation (9) delivers a firm-specific measure of the implied expected one-period ahead return (IER). Following prior literature (e.g., Campbell, 1991; Vuolteenaho, 2002), when examining the relationship between the IER and realized future stock returns, we consider cash flow news (CFN) and discount rate news (DRN). CFN equals actual earnings per share for year $t+l$ less analysts' forecasts of one-year ahead earnings per share or 'earnings surprise', scaled by stock price at time $t$. Vuolteenaho (2002) suggests that time $t$ discount rate news proxy is a function of the time $t+1$ change in the implied expected returns and discount rate news may not affect all companies equally. Hence, consistent with Easton and Monahan (2005, 2016), time $t$ discount rate news (DRN), is proxied by $\left(I E R_{j, t}-I E R_{j, t-1}\right)$ for firm $j$ in the analysis. ${ }^{23}$

\footnotetext{
${ }^{23}$ Note Botosan et al. (2011) argue that DRN is an economy-wide discount rate news proxy. In their analysis, DRN is measured by the one-year ahead change in the yields of the five-year treasury constant maturity as of the month the expected return estimates. If we use their measure, DRN becomes less significant, while the main results are similar.
} 
Following Fama and French (1989) and others, term spread and default spread are also considered. Term Spread is calculated as the difference between 10-Year US Treasury constant maturity rate and the 3-month US T-Bill yields. Default Spread is calculated as the difference between Moody's Seasoned Baa and Aaa Corporate Bond yields. Data on corporate bonds and US T-Bills/Bonds are obtained from the FRED database of the Federal Reserve Bank of St. Louis. Further, it may be reasonable to delete firm-year observations with the implied expected one-year ahead return less than the risk-free rate if the IER is qualified as a proxy for the expected return (Easton (2009)). ${ }^{24}$ In the following analysis of the characteristics of expected return such firm-year observations are eliminated. ${ }^{25}$ Our interest is in the association between excess one-year ahead realized returns (XRET1) and excess implied expected risk premium (ERP).

<Insert Table 4 about here>

Table 4 Panel A provides descriptive statistics pertaining to XRET1, ERP, and other risk proxies. Mean and median estimates of the expected risk premium are $4.7 \%$ and $3.5 \%$ respectively. ${ }^{26}$ While the median XRET1, 3.6\% falls within the range of the expected risk premium, its standard deviation of $60.2 \%$ greatly exceeds the standard deviation of ERP. Panel A also provides descriptive statistics for proxies of cash flow news, discount rate news, term spread and default spread. CFN has a mean value of -0.044 , which is statistically significantly

\footnotetext{
${ }^{24}$ There are about $24 \%$ of firm-year observations with the IER less than the risk-free rate. This includes the IERs declined between 2001-2009. Note that $31 \%$ of the firm-years in the Easton and Monahan (2005) sample (from 1981 to1998) have values of implied cost of equity capital below the risk-free rate. This suggests that the IER is a downward biased measure of expected return. The main results are similar when we drop firm-year observations with the IER less than zero instead of the risk-free rate. Further investigation shows that firms with IER $<0$ have smaller market capitalization than firms in the full sample (with median 230 vs. 335), smaller (negative) forward (forecasted) earnings yield (with median $-1.3 \%$ vs. 6.8\%) and much higher beta (with median 1.36 vs. 1.04). The averages of $\mathrm{B} / \mathrm{P}$ are 0.84 and 3.03 respectively for the full sample and firms with IER $<0$. ${ }^{25}$ The ICC literature also often further restricts the ICC less than 1. As a consequence, the ICCs usually show the low volatilities and high Sharpe ratios. This is also a limitation of the IER as a proxy of expected return. ${ }^{26}$ If we keep firm-year observations with the IER less than the risk-free rate but greater than 0 , then mean and median estimates of the ERP are $3.46 \%$ and $2.75 \%$ respectively. Note that the number of observations for XRET1 is slightly smaller than that of IERs since 12 consecutive monthly returns are required to calculate the annual return of a firm.
} 
negative at the $1 \%$ level, suggesting optimism in analysts' earnings forecasts. The mean of DRN is -0.012 also significantly negative, indicating an average annual decline in the IER over the sample period. The means of term spread and default spread are 1.685 and 1.095 respectively. The statistics also describe a sample where average market risk is comparable with that of the market portfolio with a mean (median) beta of $1.058(0.984)$ and a mean (median) debt-to-equity ratio of $69.9 \%(26 \%)$.

Table 4 Panel B presents pair-wise correlations among a set of variables applied in the regression analysis. It shows that the proxy of expected risk premium ERP correlates positively with XRET1 with $\rho=0.139$. As expected, the correlation between XRET1 and CFN is positive ( $\rho=0.194)$, and that between XRET1 and DRN is negative ( $\rho=-0.159)$. These correlations are significant at the $1 \%$ level, suggesting cash flow news and discount rate news play an important role in explaining realized returns. Consistent with prior literature, XRET1 is positively related to leverage and beta, and is negatively related to the size (Fame and French $(1992,1993,1995))$. Unexpected return, the difference between XRET1 and ERP, also correlates positively with cash flow news, beta, leverage, term spread and default spread, and negatively with discount rate news and firm size in a theoretically predictable manner.

Table 4 Panel C documents IER's out-of-sample predictive ability with respect to future stock returns by sorting firms into quintiles of implied expected return distribution at the end of March of each year. For each portfolio, the mean buy-and-hold return for the next 12 months is calculated. Hedge returns as the difference in returns between the top (Q5) and bottom (Q1) quintiles of IERs are also calculated. It shows that the IER exhibits a monotonic relation with future realized returns. The difference in realized returns over 12-months between the top and bottom quintiles of IER, Q5-Q1, is equal to 8.7\%. If the hedge returns represent the expected return effect, intuitively, the magnitude of the hedge returns should persist. Panel C, indeed, 
shows that the average realized return spreads between quintiles 5 and 1 is $46.6 \%$ for 60 -month buy-and-hold returns.

Next, we examine the excess return predictive ability of expected risk premium, ERP, at the firm level. We also investigate the cross-sectional relation between a set of conventional risk characteristics and ex post realized return. All regressions are based on a pooled sample, with year fixed effects and standard errors clustered by firm and year as in Petersen (2009). ${ }^{27}$ Table 5 reports coefficients and their t-statistics (in brackets) for these regressions.

\section{<Insert Table 5 about here>}

Notably, no matter what risk proxies we control for, the implied risk premium has significant explanatory power to excess one-year ahead realized returns. Both CFN and DRN have significant incremental roles in explaining future realized returns. Specifically, the result of univariate regression of excess realized returns on expected risk premium in Table 5 column 2 shows that ERP is positively related to XRET1 with a coefficient of 1.83 , which is not statistically different from $1 .^{28}$ When we include our proxies for cash flow news and discount rate news in the regression, it shows a strong positive relation between excess realized returns and cash flow news and a strong negative relation between excess realized returns and discount rate news. Adjusted R-squareds increase from $1.93 \%$ to $8.02 \%$. When we include term spread and default spread, the result is similar. The adjusted R-squareds increase from $1.93 \%$ to $8.94 \%$. This result is consistent with our expectation and with results documented in Voulteenaho (2002) and Botosan et al. (2011). While XRET1 being positively related to beta and leverage, and negatively related to firm size accords with expectations, neither market beta nor leverage is significantly related to excess future realized returns if book-to-market is included in the

\footnotetext{
${ }^{27}$ Fama-MacBeth regressions show more significant results in statistical sense.

${ }^{28}$ The regression coefficient of the difference between XRET1 and ERP on expected risk premium is 0.83 with t-statistic of 1.19 .
} 
regression. When including book-to-market in the analysis, both term spread and default spread have the correct signs but are not statistically significant at the 5\% level. The coefficient of book-to-market itself is positive and highly significant.

Given firm characteristics including growth of future investments, book-to-market, earningsto-price, dividends-to-price and past returns are the main inputs in the estimation of the IER, we only examine the relationship between expected risk premium (ERP) and the CAPM beta, size, leverage, total risk, term spread and default spread to avoid drawing potential spurious inferences (Botosan and Plumlee (2005), Easton and Monahan (2016)). ${ }^{29}$ Based on prior empirical studies on the cross sectional determinants of returns, we expect the expected return to be positively associated with beta, leverage, standard deviation of annual return and risk spreads, and to be negatively associated with firm size.

<Insert Table 6 about here>

Table 6 shows that the results of univariate and multivariate regressions of the expected risk premium on market beta, firm size and leverage are all in the theoretically predicted directions. Specifically, the expected risk premium is significantly positively related to beta and leverage, but negatively related to firm size. However, when we control for total risk, there is an insignificant negative relation between the implied risk premium and beta. The total risk itself is strongly positively related to EPR, reflecting a property that the I/B/E/S analysts' forecasts taking into account more total risk than the firm's systematic risk ${ }^{30}$ In addition, the coefficient of beta is very stable in magnitude whether we use univariate or multivariate regressions if excluding total risk. When we include term spread and default spread into the regressions, we

\footnotetext{
${ }^{29}$ Botosan and Plumlee (2005) argue that spurious effects are likely for most (perhaps all) implied cost of capital estimates by including book-to-market and earnings yield. It is evident that the adjusted R-squareds are nearly 59\% when earnings yield and forward earnings yield are included in our regression analysis.

${ }^{30}$ Hail and Leuz (2006) also suggest that the implied cost of capital seems to be more closely related to stock return volatility than to beta.
} 
find that default spread is statistically significantly related to the implied risk premium.

However, term spread shows a negative relation though it is not statistically significant.

\subsection{Robustness test}

Although using benchmark industry averages in the valuation of an individual firm is a longstanding industry practice, grouping firms based on industry classification is known to be difficult to ensure homogeneity of firms. Further sorting based on firms' characteristics is a natural extension. ${ }^{31}$ Since the size of different firms within an industry can be significantly different and size is one of the most important characteristics of a firm, we further group firms according to their size quintiles in each industry-year portfolio to infer the firm-specific IER. ${ }^{32}$ We sort size into 5-quintiles for each of the 150 industry-year portfolios. To increase the observations for each of the 750 portfolios in an industry-year-size analysis, a five-year rolling window for 30-year over 1980-2009 is used.

We repeat the analysis above to estimate the average growth rate, cost of capital, valuation multiples and conservatism parameter for each industry-year-size portfolio, $\bar{g}_{i j t}, \bar{R}_{i j t}, \bar{\beta}_{1, i j t}, \bar{\beta}_{2, i j t}$ and $\bar{\lambda}_{i j t}$, via equation (8), where $i=1-5$ and $j=1-5$ represent industry and size respectively. A modified equation (9) then gives firm-specific proxy of expected returns at year $t$ :

$$
\begin{aligned}
I E R_{t} & =\left(1+\bar{g}_{i j t}\right)\left[1-\frac{b_{t}}{P_{t}}-\left(\bar{\beta}_{1, i j t}-\left(\bar{R}_{i j t}-1\right) \bar{\beta}_{2, i j t}\right) \frac{b_{t-1}}{P_{t}}-\left(\bar{\beta}_{1, j i t}+\bar{\beta}_{2, i j t}\right) \frac{x_{t}}{P_{t}}\right]+\left(1+\bar{\beta}_{1, i j t}+\bar{\beta}_{2, i j t}\right) \frac{E_{t}\left[x_{t+1}\right]}{P_{t}} \\
& +\left(1+\bar{\beta}_{1, i j t}-\left(\bar{R}_{i j t}-1\right) \bar{\beta}_{2, i j t}\right) \frac{b_{t}}{P_{t}}+\bar{\lambda}_{i j t}\left[\frac{P_{t}-b_{t}-\left(P_{t-1}-b_{t-1}\right)}{P_{t}}\right]-1,
\end{aligned}
$$

$<$ Insert Table 7 about here>

\footnotetext{
${ }^{31}$ In addition, analysts' forecast errors are believed to weaken the association between the implied cost of capital and realized returns (Hughes et al. (2008)). To mitigate the effect of analysts' bias, we also adjust the consensus forecasts for predictable errors. The main results, not reported here, are improved only slightly.

${ }^{32}$ Firms in the industry-year portfolios are also further sorted based on firms' book-to-market ratio or their past realized returns instead of size. The results are similar. We do not report the detailed results of these tests, but they are available on request.
} 
The result of univariate regression of excess realized returns (XRET1) on expected risk premium (ERP) in Table 7 column 2 shows that ERP is positively related to XRET1 with coefficient of 1.74 , which is not statistically different from 1 . The adjusted R-squared is similar to the IER based on the industry-year portfolios. The results of multivariate regressions are also similar to those when we use the industry-year portfolios. When we include the proxies for cash flow and discount rate news in the regression, we find the slope increases to 2.06 and CFN and DRN have significant incremental explanatory power. The adjusted R-squared increases from $1.96 \%$ to $7.43 \%$. While XRET1 is positively related to beta and negatively related to firm size accord with expectations, only size but not beta is statistically significant when we control for the proxy for the implied risk premium. While it shows strong positive (negative) relations between realized returns and cash flow news (discount rate news), the relations between future realized returns and term spread and default spread are not significant at the 5\% level. When including book-to-market in the analysis, however, the coefficient of leverage is not statistically significant, although it still has the correct sign. The coefficient of book-to-market itself is positive and highly significant.

\section{$<$ Insert Table 8 about here>}

Table 8 shows that the results of univariate and multivariate regressions of expected risk premium on market beta, firm size, leverage, and other risk characteristics. The results confirm and strengthen the findings that market beta is significantly positively related to the implied risk premium. Moreover, the expected risk premium is significantly positively related to leverage and default spread, and negatively related to firm size. The coefficient of term spread is positive though not statistically significant. Beta is still negatively related to the implied risk premium when we control for firm's total risk, which itself is strongly positively related to EPR. It indicates that analysts' forecasts of earnings reflect more total risk than the firm's systematic risk. 


\section{Conclusion}

An increasing number of studies in finance and accounting use the implied cost of equity capital as a proxy for expected stock return. However, the validity of this proxy is often challenged from the following two aspects. There is often an insignificant or negative relation between the proxy and future realized stock returns, and the evidence on the cross-sectional relation between the proxy and established risk characteristics is mixed.

In this paper, we introduce a computationally-simple methodology to derive firm-specific expected one-period ahead stock returns. Our approach builds on recent accounting based valuation models developed by Clubb (2013) and Ashton and Wang (2013). We show that the firm-specific measure of the implied expected return is intrinsically linked to commonly used financial ratios including book-to-market, (forward) earnings yield, dividend-to-price as well as growth and past returns. The expression yields the insight that expected returns are associated with the risk that is related to uncertainty about future growth of the net present value in future investments. It provides an explanation as to why the book-to-market $(B / P)$ ratio may be useful for explaining expected stock returns. Forward earnings yield is identified as an omitted factor in the Fama and French factor model. It also shows that accounting conservatism can cause time-serial correlation in stock returns.

Our implementation of the model incorporates endogenously estimated valuation parameters including the expected long term growth rates of the net present value of future investments and long term cost of capital on industry-year portfolios. We demonstrate that the proxy of expected return developed in this paper is significantly positively associated with future realized stock returns. The measure remains significantly positively related to future realized stock returns even after controlling for commonly used risk proxies. It also significantly correlates with commonly used risk characteristics, such as the CAPM beta, size, leverage and 
default spread, in a theoretically predictable manner. The results of this study are likely to be of interest to practitioners and managers in making capital allocation decisions and to academics in need of proxies for firms' discount rates and expected returns. 


\section{REFERENCES}

Ashton, D. and P. Wang (2013), 'Terminal Valuations, Growth Rates and the Implied Cost of Capital', Review of Accounting Studies, Vol.18, No.1, pp. 261-290.

Berk, J., R. Green, and V. Naik (1999), 'Optimal Investment, Growth Options, and Security Returns', Journal of Finance, Vol.54, pp.1153-1608.

Botosan, C., and M.A. Plumlee (2005), 'Assessing Alternative Proxies for the Expected Risk Premium', The Accounting Review, Vol.80, pp.21-53.

Botosan, C., M. A. Plumlee, and H. J. Wen (2011), 'The Relation between Expected Returns, Realized Returns, and Firm Risk Characteristics', Contemporary Accounting Research, Vol.28, No.4, pp.1085-1122.

Callen, J. (2016), 'Accounting Valuation and Cost of Equity Capital Dynamics', Abacus Vol.52, No.1, pp.5-25.

Campbell, J. (1991), 'A Variance Decomposition for Stock Returns', The Economic Journal, Vol.101, pp.157-179.

Chava, S., and A. Purnanadam (2010), 'Is Default Risk Negatively Related to Stock Returns?', Review of Financial Studies, Vol. 23, pp.2523-2559.

Chen, Z., Y. Huang and K.C. Wei (2013), 'Executive Pay Disparity and the Cost of Equity Capital', Journal of Financial and Quantitative Analysis, Vol.48, pp.849-885.

Christodoulou, D., C. Clubb and S. McLeay (2016), 'A Structural Accounting Framework for Estimating the Expected Rate of Return on Equity', Abacus, Vol.52, No.1, pp.176-210.

Claus, J., and J. Thomas (2001), 'Equity Premia as Low as Three Percent? Evidence from Analysts' Earnings Forecasts for Domestic and International Stock Markets', The Journal of Finance, Vol.56, pp.1629-1666.

Clubb C. (2013), 'Information Dynamics, Dividend Displacement, Conservatism, and Earnings Measurement: a Development of the Ohlson (1995) Valuation Framework', Review of Accounting Studies, Vol.18, No.2, pp.360-385.

Collins, D.W., M. Pincus and H. Xie (1999), 'Equity Valuation and Negative Earnings: the Role of Book Value of Equity', Accounting Review, Vol.74, No.1, pp.29-61.

Cooper, M., H. Gulen, and M. Schill (2008), 'Asset Growth and the Cross-Section of Stock Returns', Journal of Finance, Vol.63, pp.1609-1651.

Damodaran, A. (2002), Damodaran on Valuation (2nd ed.). New York: Wiley.

Dargenidou C., S.J.McLeay and I.Raonic (2006), 'Expected Earnings Growth and the Cost of Capital: an Analysis of Accounting Regime Change in the European Financial Market', Abacus, Vol.42, No.3-4, pp.388-414.

Easton, P.D. (2009), 'Estimating the Cost of Capital Implied by Market Price and Accounting Data', Foundations and Trends in Accounting, Vol.2, pp.241-364. 
Easton, P.D., G. Taylor, P. Shroff, and T. Sougiannis (2002), 'Using Forecasts of Earnings to Simultaneously Estimate Growth and the Rate of Return on Equity Investment', Journal of Accounting Research, Vol.40, pp.657-676.

Easton, P.D. and S. Monahan (2005), 'An Evaluation of Accounting-based Measures of Expected Returns', Accounting Review, Vol.80, pp.501-38.

Easton, P.D. and S. Monahan (2016), 'Review of Recent Research on Improving Earnings Forecasts and Evaluating Accounting-based Estimates of the Expected Rate of Return on Equity Capital', Abacus, Vol.52, No.1, pp.35-58.

Fama, E., and K. French (1988), 'Dividend Yields and Expected Stock Returns', Journal of Financial Economics, Vol.22, pp.3-25.

Fama, E., and K. French (1989), 'Business Conditions and Expected Returns on Stocks and Bonds', Journal of Financial Economics, Vol.25, pp.23-49.

Fama, E., and K. French (1992), 'The Cross-Section of Expected Stock Returns', Journal of Finance, Vol.47, pp.427-465.

Fama, E., and K. French (1993), 'Common Risk Factors in the Returns of Stocks and Bonds', Journal of Financial Economics, Vol.33, pp.3-56.

Fama, E., and K. French (1997), 'Industry Costs of Equity', Journal of Financial Economics, Vol.43, pp.153- 193.

Fama, E., and K. French (2006), 'Profitability, Investment and Average Returns', Journal of Financial Economics, Vol.82, pp.491-518.

Gebhardt, W., C. Lee, and B. Swaminathan (2001), 'Toward an Implied Cost of Capital', Journal of Accounting Research, Vol.39, pp.135-176.

Gode, D., and P. Mohanram (2003), 'Inferring Cost of Capital Using the Ohlson-Juettner Model', Review of Accounting Studies, Vol.8, pp.339-431.

Hail, L. and C. Leuz (2006), 'International Differences in Cost of Capital: Do Legal Institutions and Securities Regulation Matter?', Journal of Accounting Research, Vol.44, pp.485-531.

Hail, L. and C. Leuz (2009), 'Cost of Capital Effects and Changes in Growth Expectations Around U.S. Cross-Listings', Journal of Financial Economics, Vol.93, pp.428-454.

Hou, K., M. van Dijk and Y. Zhang (2012), 'The Implied Cost of Capital: A New Approach', Journal of Accounting and Economics, Vol.3, No.3, pp.504-526.

Hughes, J., J. Liu, and W. Su (2008), 'On the Relation between Predictable Market Returns and Predictable Analyst Forecast Errors', Review of Accounting Studies, Vol.13, pp.266-291.

Johnstone, D. (2016), 'Advances in Equity Valuation: Research on Accounting Valuation', Abacus, Vol.52, No.1, pp.1-4.

Kaplan, S.N. and R.S. Ruback (1995), 'The Valuation of Cash Flow Forecasts: an Empirical Analysis', The Journal of Finance, Vol.50, pp.1059-1093. 
Lee, C. M. C., D. Ng, and B. Swaminathan (2009), 'Testing International Asset Pricing Models Using Implied Costs of Capital', Journal of Financial and Quantitative Analysis, Vol.44, pp.307-335.

Lee, C., and B. Swaminathan (2000), 'Price Momentum and Trading Volume', The Journal of Finance, Vol.55, No.5, pp.2017-2069.

Liew, J., and M. Vassalou (2000), 'Can Book-to-Market, Size and Momentum Be Risk Factors that Predict Economic Growth?', Journal of Financial Economics, Vol.57, pp.221245.

Lintner, J. (1965), 'The Valuation of Risk Assets and the Selection of Risky Investments in Stock Portfolios and Capital Budgets', The Review of Economics and Statistics, Vol.47, pp.13-37.

Liu, J., D. Nissim, and J. Thomas (2002), 'Equity Valuation Using Multiples', Journal of Accounting Research, Vol.40, pp.135-172.

Lyle, M.R., J.L. Callen and R.J. Elliott (2013), 'Dynamic Risk, Accounting-Based Valuation and Firm Fundamentals', Review of Accounting Studies, Vol.18, No.4, pp.899-929.

Miller, M., and F. Modigliani (1961), 'Dividend Policy, Growth and the Valuation of Shares', Journal of Business, Vol.34, pp.411-433.

Modigliani, F. and M. Miller (1958), 'The Expected Cost of Equity Capital, Corporation Finance, and the Theory of Investment', American Economic Review, (June), pp.261-97.

Ohlson, J. (1995), 'Earnings, Book Values, and Dividends in Security Valuation', Contemporary Accounting Research, Vol.11, pp.661-687.

Ohlson, J. (2005), 'A Simple Model Relating the Expected Return (Risk) to the Book-toMarket and the Forward Earnings-to-Price Ratios', Working paper, Arizona State University.

Pastor, L., M. Sinha, and B. Swaminathan (2008), 'Estimating the Intertemporal RiskReturn Tradeoff Using the Implied Cost of Capital', The Journal of Finance, Vol.63, pp.2859-2897.

Penman, S. (2010), Financial Statement Analysis and Security Valuation, 4th ed. New York, The McGraw-Hill Companies.

Penman, S. (2016), 'Valuation: Accounting for Risk and the Expected Return', Abacus, Vol.52, No.1, pp.106-130.

Penman, S. and J.L. Zhu (2014), 'Accounting Anomalies, Risk, and Return', Accounting Review, Vol.89, pp.1835-1866.

Penman, S., F. Reggiani, S.A. Richardson and I. Tuna (2014), 'A Characteristic Model for Asset Pricing', Working paper, London Business School.

Petersen, M.A. (2009), 'Estimating Standard Errors in Finance Panel Data Sets: Comparing Approaches', The Review of Financial Studies, Vol.22, pp.435-480.

Pope, F.P. and P. Wang (2005), 'Earnings Components, Accounting Bias and Equity Valuation', Review of Accounting Studies, Vol.10, pp.387-407. 
Sharpe, W. (1964), 'Capital Asset Price: a Theory of Market Equilibrium under Conditions of Risk', Journal of Finance, Vol.19, pp.425-42.

Vassalou, M. (2003), 'News Related to Future GDP Growth As a Risk Factor in Equity Returns', Journal of Financial Economics, Vol.68, pp.47-73.

Vuolteenaho, T. (2002), 'What Drives Firm-Level Stock Returns?', Journal of Finance, Vol.57, pp.233-264. 


\section{Appendix:}

Equation (1) implies

$$
P_{t+1}+d_{t+1}=\left[1+\beta_{1}-(R-1) \beta_{2}\right]\left(b_{t+1}+d_{t+1}\right)+R \beta_{2} x_{t+1}+\vartheta_{t+1} .
$$

Note the clean surplus identity: $b_{t+1}+d_{t+1}=b_{t}+x_{t+1}$, we have

$$
\begin{gathered}
P_{t+1}+d_{t+1}=\left[1+\beta_{1}-(R-1) \beta_{2}\right] b_{t}+\left[1+\beta_{1}+\beta_{2}\right] x_{t+1}+\vartheta_{t+1}, \\
\frac{P_{t+1}+d_{t+1}}{P_{t}}=\left[1+\beta_{1}-(R-1) \beta_{2}\right] \frac{b_{t}}{P_{t}}+\left[1+\beta_{1}+\beta_{2}\right] \frac{x_{t+1}}{P_{t}}+\frac{\vartheta_{t+1}}{P_{t}}
\end{gathered}
$$

Using equation (2) and rewriting equation (1) as:

$\vartheta_{t}=P_{t}-\left[1+\beta_{1}-(R-1) \beta_{2}\right] b_{t}-\left[\beta_{1}-(R-1) \beta_{2}\right] d_{t}-R \beta_{2} x_{t}$, it follows from equation (3) that

$$
\begin{aligned}
\frac{P_{t+1}+d_{t+1}}{P_{t}}= & {\left[1+\beta_{1}-(R-1) \beta_{2}\right] \frac{b_{t}}{P_{t}}+\left[1+\beta_{1}+\beta_{2}\right] \frac{x_{t+1}}{P_{t}}+\frac{\varepsilon_{t+1}}{P_{t}} } \\
& +\frac{(1+g)\left(P_{t}-\left[1+\beta_{1}-(R-1) \beta_{2}\right] b_{t}-\left[\beta_{1}-(R-1) \beta_{2}\right] d_{t}-R \beta_{2} x_{t}\right)+\lambda\left(P_{t}+d_{t}-P_{t-1}-x_{t}\right)}{P_{t}} \\
= & (1+g)+\left[1+\beta_{1}-(R-1) \beta_{2}\right] \frac{b_{t}}{P_{t}}+\left[1+\beta_{1}+\beta_{2}\right] \frac{x_{t+1}}{P_{t}}+\frac{\lambda\left(P_{t}+d_{t}-P_{t-1}-x_{t}\right)}{P_{t}}+\frac{\varepsilon_{t+1}}{P_{t}} \\
& +\frac{(1+g)\left(-\left[1+\beta_{1}-(R-1) \beta_{2}\right]\left(b_{t-1}+x_{t}-d_{t}\right)-\left[\beta_{1}-(R-1) \beta_{2}\right] d_{t}-R \beta_{2} x_{t}\right)}{P_{t}}
\end{aligned}
$$

Hence

$$
\begin{aligned}
\frac{P_{t+1}+d_{t+1}}{P_{t}} & =(1+g)+\frac{(1+g) d_{t}}{P_{t}}+\left[1+\beta_{1}-(R-1) \beta_{2}\right] \frac{b_{t}-(1+g) b_{t-1}}{P_{t}} \\
& +\left[1+\beta_{1}+\beta_{2}\right] \frac{x_{t+1}-(1+g) x_{t}}{P_{t}}+\frac{\lambda\left(P_{t}+d_{t}-P_{t-1}-x_{t}\right)}{P_{t}}+\frac{\varepsilon_{t+1}}{P_{t}} .
\end{aligned}
$$

Replacing $d_{t}$ by $d_{t}=x_{t}+b_{t-1}-b_{t}$, equation (4) can be rewritten as

$$
\begin{aligned}
& \frac{P_{t+1}+d_{t+1}}{P_{t}}=(1+g)\left(1-\frac{b_{t}}{P_{t}}-\left[\beta_{1}-(R-1) \beta_{2}\right] \frac{b_{t-1}}{P_{t}}-\left[\beta_{1}+\beta_{2}\right] \frac{x_{t}}{P_{t}}\right) \\
& +\left[1+\beta_{1}-(R-1) \beta_{2}\right] \frac{b_{t}}{P_{t}}+\left[1+\beta_{1}+\beta_{2}\right] \frac{x_{t+1}}{P_{t}}+\lambda \frac{\left(P_{t}-b_{t}-\left(P_{t-1}-b_{t-1}\right)\right)}{P_{t}}+\frac{\varepsilon_{t+1}}{P_{t}}
\end{aligned}
$$


Taking expectation on both sides of equation (6), and noting the no-arbitrage condition: $E_{t}\left[P_{t+1}+d_{t+1}\right]=R P_{t}$, where $E_{t}[]$ represents expectation based on available information at time $\mathrm{t}$, equation (6) can be rewritten as

$$
\begin{aligned}
E_{t}\left[x_{t+1}\right] & =\frac{R-(1+g)-\lambda}{\left(1+\beta_{1}+\beta_{2}\right)} P_{t}+\frac{(1+g)\left(\beta_{1}+\beta_{2}\right)}{\left(1+\beta_{1}+\beta_{2}\right)} x_{t}+\frac{g-\beta_{1}+(R-1) \beta_{2}+\lambda}{\left(1+\beta_{1}+\beta_{2}\right)} b_{t} \\
& +\frac{(1+g)\left(\beta_{1}-(R-1) \beta_{2}\right)-\lambda}{\left(1+\beta_{1}+\beta_{2}\right)} b_{t-1}+\frac{\lambda}{\left(1+\beta_{1}+\beta_{2}\right)} P_{t-1} .
\end{aligned}
$$

Denote $E_{t}\left[x_{t+1}\right]=\delta_{1} P_{t}+\delta_{2} x_{t}+\delta_{3} b_{t}+\delta_{4} b_{t-1}+\delta_{5} P_{t-1}$ as in equation (8). It follows equation (7) that

$$
\begin{gathered}
1+g=\frac{1+\delta_{2}+\delta_{3}-\delta_{5}+\sqrt{\left(1+\delta_{2}+\delta_{3}-\delta_{5}\right)^{2}-4\left(\delta_{2}-\delta_{4}-\delta_{5}\right)}}{2}, \\
R=(1+g)\left(1+\frac{\delta_{1}+\delta_{5}}{1+g-\delta_{2}}\right), \\
\beta_{1}=\frac{(R-1) \delta_{2}+\delta_{4}+\delta_{5}}{(1+g)\left(1+g-\delta_{2}\right)}, \beta_{2}=\frac{\delta_{2}-\left(\delta_{4}+\delta_{5}\right)}{R\left(1+g-\delta_{2}\right)}, \lambda=\frac{(1+g) \delta_{5}}{1+g-\delta_{2}} .
\end{gathered}
$$




\section{Figure 1}

\section{The Relation Between Estimates of the Cost of Capital, Growth Rate and Risk Premium}

This figure shows the trends of the implied long term average cost of capital, growth rate and risk premium over 1980-2009. Risk premium is equal to the difference between the implied cost of capital and 10-year US government bond yields. Growth is the expected growth rate of the NPV of future investment implied in the analysts' forecasts of earnings.

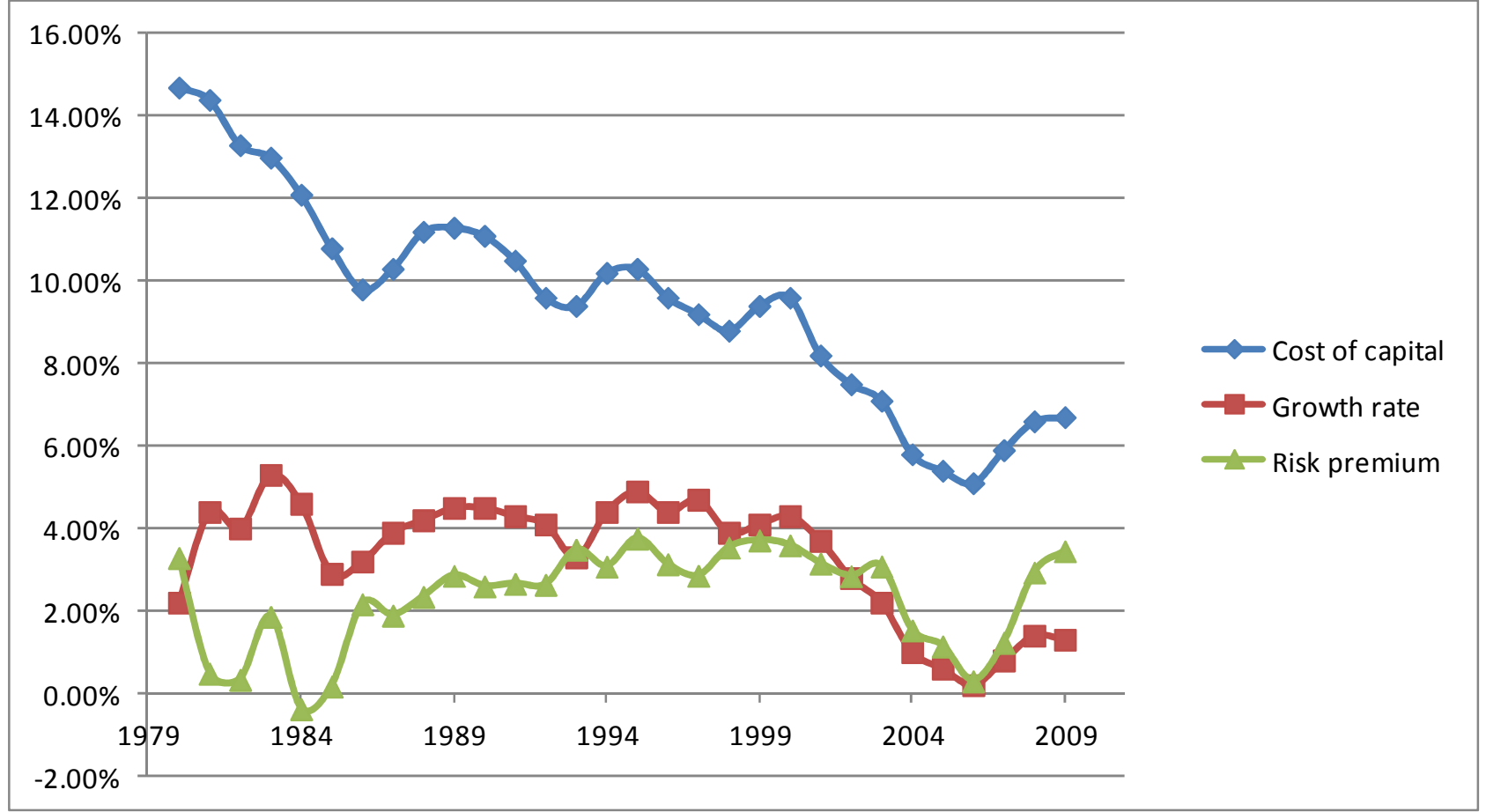


Table 1

\section{Sample Descriptive Statistics and Correlation Matrix}

Panel A shows descriptive statistics for 60,170 firm-years between 1980 and 2010 . Observations outside the $1^{\text {st }}$ and $99^{\text {th }}$ percentiles for book value, earnings, price and number of shares outstanding are deleted. The mean, standard deviation (stdev), median, and $1 \%$ and $99 \%$ are reported. feps is the median consensus forecasts of earnings at the first month after the corresponding I/B/E/S-reported prior-year earnings announcements. Price (P) is stock price 3-months after the fiscal year-end. bps and eps are book value per share and earnings per share respectively. Earnings are net income per share before extraordinary items. B/P and E/P are the book-to-market ratio and earnings-to-price ratio respectively. FE/P is one-year ahead I/B/E/S consensus forecasts of earnings scaled by price. Mktcap is market capitalization 3-months after the fiscal year-end. LEV is total debt divided by the firm's market capitalization 3 months after the fiscal year-end.

Panel B shows the annual cross-sectional correlations for 60,170 firm-year observations. The upper (lower) right triangle of the matrix shows Spearman (Pearson) correlations.

\begin{tabular}{|c|c|c|c|c|c|c|c|c|c|}
\hline \multicolumn{10}{|c|}{ Panel A: Sample Statistics } \\
\hline & feps & $\mathrm{P}$ & bps & eps & $\mathrm{B} / \mathrm{P}$ & $\mathrm{E} / \mathrm{P}$ & $\mathrm{FE} / \mathrm{P}$ & Mktcap & Lev \\
\hline $\mathrm{N}$ & 60170 & 60170 & 60170 & 60170 & 60170 & 60170 & 60170 & 60170 & 60170 \\
\hline mean & 1.108 & 16.630 & 11.180 & 1.091 & 0.840 & 0.048 & 0.067 & 1683.000 & 0.884 \\
\hline stdev & 1.035 & 12.730 & 22.650 & 3.177 & 2.342 & 0.318 & 0.077 & 4759.000 & 5.718 \\
\hline $\mathrm{p} 1$ & -0.990 & 1.338 & 0.549 & -3.078 & 0.072 & -0.628 & -0.193 & 12.020 & 0.000 \\
\hline p25 & 0.410 & 7.000 & 3.693 & 0.194 & 0.344 & 0.022 & 0.045 & 108.100 & 0.040 \\
\hline p50 & 0.900 & 13.380 & 7.148 & 0.703 & 0.557 & 0.054 & 0.068 & 335.000 & 0.240 \\
\hline p75 & 1.600 & 22.820 & 12.610 & 1.447 & 0.859 & 0.084 & 0.094 & 1172.000 & 0.720 \\
\hline p99 & 4.550 & 58.750 & 73.990 & 10.020 & 5.524 & 0.613 & 0.245 & 23079.000 & 9.442 \\
\hline \multicolumn{10}{|c|}{ Panel B: Correlation Matrix (Pearson Bottom; Spearman Top) } \\
\hline & feps & $\mathrm{P}$ & bps & eps & $\mathrm{B} / \mathrm{P}$ & $\mathrm{E} / \mathrm{P}$ & $\mathrm{FE} / \mathrm{P}$ & Mktcap & Lev \\
\hline feps & & 0.762 & 0.695 & 0.829 & 0.002 & 0.489 & 0.485 & 0.437 & 0.193 \\
\hline $\mathrm{P}^{1}$ & 0.716 & & 0.635 & 0.648 & -0.313 & 0.105 & -0.104 & 0.642 & -0.037 \\
\hline bps & 0.275 & 0.240 & & 0.629 & 0.471 & 0.335 & 0.228 & 0.289 & 0.367 \\
\hline eps & 0.383 & 0.295 & 0.794 & & 0.036 & 0.744 & 0.396 & 0.388 & 0.161 \\
\hline $\mathrm{B} / \mathrm{P}$ & -0.021 & -0.094 & 0.641 & 0.434 & & 0.300 & 0.413 & -0.366 & 0.494 \\
\hline $\mathrm{E} / \mathrm{P}$ & 0.178 & 0.073 & 0.501 & 0.627 & 0.673 & & 0.683 & 0.038 & 0.254 \\
\hline $\mathrm{FE} / \mathrm{P}$ & 0.439 & -0.015 & 0.073 & 0.156 & 0.066 & 0.282 & & -0.154 & 0.364 \\
\hline Mktcap & 0.286 & 0.431 & 0.045 & 0.095 & -0.051 & 0.014 & -0.019 & & -0.054 \\
\hline Lev & 0.002 & -0.046 & 0.362 & 0.261 & 0.653 & 0.497 & 0.050 & -0.014 & \\
\hline
\end{tabular}


Table 2

\section{Regressing Forecasted Earnings on Price, Earnings, Book Value, Lagged Book Value and Lagged Price}

Table 2 reports the regression coefficients (t-values) of $\delta_{\mathrm{i}}$ (i=1-5) in $\frac{f e p s_{t+1}}{P_{t}}=\delta_{1}+\delta_{2} \frac{e_{t}}{P_{t}}+\delta_{3} \frac{b_{t}}{P_{t}}+\delta_{4} \frac{b_{t-1}}{P_{t}}+\delta_{5} \frac{P_{t-1}}{P_{t}}+\varepsilon_{t+1}$ for each of the 150 industry-year portfolios based on the estimates in a two-year rolling window between 1980-2009. Industry classification for 5-industries is per Ken French's website. Observations with any of the dependent or independent variables in the top and bottom $1 \%$ of observations are removed to reduce the effects of outliers. feps $s_{t+1}$ is the median consensus forecasts of earnings at the first month after the corresponding I/B/E/S-reported prior-year earnings announcements; $P_{t}$ and $P_{t-l}$ are the contemporary stock price and lagged stock price respectively; $b_{t}$ and $b_{t-1}$ are the contemporary book value of equity and lagged book value of equity respectively; $e_{t}$ is net income before extraordinary items. $\mathrm{N}$ is the number of observations in a two-year rolling window. The descriptive statistics, including mean, standard deviation, minimum, lower quartile, median, upper quartile and maximum, are also reported. Panels A and B report the results on a year-by-year basis and industry-by-industry basis respectively.

\begin{tabular}{|c|c|c|c|c|c|c|c|c|c|c|c|c|}
\hline \multicolumn{13}{|c|}{ Panel A: by year, mean value for 5-industry } \\
\hline Year & $\delta_{1}$ & t-stat & $\delta_{2}$ & t-stat & $\delta_{3}$ & t-stat & $\delta_{4}$ & t-stat & $\delta_{5}$ & t-stat & $\operatorname{adj}-R^{2}$ & $\mathrm{~N}$ \\
\hline $79-80$ & 0.046 & 6.25 & 0.469 & 7.00 & 0.006 & 0.18 & 0.009 & 0.66 & 0.020 & 2.20 & $54.06 \%$ & 1682 \\
\hline $80-81$ & 0.045 & 6.84 & 0.392 & 6.70 & 0.017 & 0.51 & 0.011 & 0.61 & 0.015 & 2.47 & $52.63 \%$ & 1812 \\
\hline $81-82$ & 0.040 & 6.62 & 0.363 & 6.93 & -0.005 & -0.29 & 0.033 & 1.44 & 0.019 & 3.46 & $51.29 \%$ & 2013 \\
\hline $82-83$ & 0.031 & 6.26 & 0.375 & 7.70 & 0.030 & 0.47 & 0.002 & 0.89 & 0.019 & 3.55 & $51.76 \%$ & 2284 \\
\hline $83-84$ & 0.034 & 6.44 & 0.359 & 7.68 & 0.043 & 1.43 & -0.012 & -0.04 & 0.015 & 3.16 & $47.78 \%$ & 2411 \\
\hline $84-85$ & 0.037 & 6.57 & 0.343 & 7.80 & -0.011 & 0.10 & 0.032 & 1.26 & 0.015 & 2.87 & $41.19 \%$ & 2491 \\
\hline $85-86$ & 0.037 & 6.56 & 0.296 & 6.91 & -0.024 & -0.57 & 0.049 & 1.96 & 0.010 & 1.53 & $33.29 \%$ & 2572 \\
\hline $86-87$ & 0.032 & 5.64 & 0.279 & 6.50 & -0.008 & 0.04 & 0.039 & 1.37 & 0.014 & 2.54 & $31.95 \%$ & 2572 \\
\hline $87-88$ & 0.038 & 5.97 & 0.306 & 6.84 & -0.008 & 0.24 & 0.039 & 1.23 & 0.011 & 2.21 & $32.95 \%$ & 2631 \\
\hline $88-89$ & 0.030 & 4.75 & 0.287 & 6.66 & 0.023 & 1.18 & 0.011 & 0.63 & 0.019 & 3.26 & $35.22 \%$ & 2840 \\
\hline $89-90$ & 0.026 & 4.91 & 0.286 & 6.21 & 0.019 & 0.69 & 0.016 & 0.85 & 0.022 & 4.24 & $38.75 \%$ & 2916 \\
\hline $90-91$ & 0.029 & 5.92 & 0.294 & 6.40 & 0.005 & -0.04 & 0.027 & 1.48 & 0.017 & 3.31 & $39.86 \%$ & 2942 \\
\hline $91-92$ & 0.037 & 7.32 & 0.272 & 5.99 & 0.009 & 0.55 & 0.022 & 0.94 & 0.005 & 1.15 & $33.63 \%$ & 3085 \\
\hline $92-93$ & 0.031 & 6.94 & 0.316 & 6.74 & -0.007 & 0.25 & 0.032 & 1.11 & 0.011 & 2.77 & $36.99 \%$ & 3362 \\
\hline $93-94$ & 0.028 & 6.19 & 0.328 & 7.24 & -0.005 & -0.14 & 0.034 & 1.56 & 0.013 & 2.84 & $36.47 \%$ & 3761 \\
\hline $94-95$ & 0.028 & 6.06 & 0.287 & 6.57 & 0.025 & 0.94 & 0.009 & 0.68 & 0.013 & 2.79 & $34.18 \%$ & 4203 \\
\hline $95-96$ & 0.027 & 7.08 & 0.266 & 6.76 & 0.018 & 0.84 & 0.015 & 0.75 & 0.013 & 2.92 & $32.16 \%$ & 4549 \\
\hline $96-97$ & 0.026 & 7.61 & 0.264 & 6.56 & 0.001 & 0.32 & 0.034 & 1.39 & 0.011 & 2.59 & $30.68 \%$ & 4744 \\
\hline $97-98$ & 0.022 & 7.57 & 0.324 & 8.74 & -0.013 & -0.20 & 0.042 & 1.89 & 0.013 & 3.94 & $37.85 \%$ & 4734 \\
\hline $98-99$ & 0.019 & 5.44 & 0.376 & 10.35 & -0.019 & -0.73 & 0.047 & 2.65 & 0.015 & 4.57 & $43.55 \%$ & 4444 \\
\hline $99-00$ & 0.025 & 6.77 & 0.345 & 7.90 & -0.018 & -0.36 & 0.049 & 2.03 & 0.012 & 3.45 & $39.41 \%$ & 4088 \\
\hline 00-01 & 0.032 & 7.35 & 0.298 & 7.22 & 0.002 & 0.46 & 0.025 & 0.76 & 0.001 & 0.57 & $33.44 \%$ & 4058 \\
\hline 01-02 & 0.033 & 8.45 & 0.286 & 7.41 & 0.011 & 0.63 & 0.009 & 0.30 & 0.001 & 0.59 & $32.83 \%$ & 4217 \\
\hline
\end{tabular}




\begin{tabular}{|c|c|c|c|c|c|c|c|c|c|c|c|c|}
\hline $02-03$ & 0.027 & 8.41 & 0.329 & 9.13 & 0.003 & 0.68 & 0.011 & 0.08 & 0.008 & 2.86 & $40.77 \%$ & 4361 \\
\hline 03-04 & 0.032 & 9.54 & 0.343 & 8.38 & 0.007 & 0.60 & 0.000 & -0.04 & 0.001 & 0.18 & $40.10 \%$ & 4670 \\
\hline 04-05 & 0.032 & 8.58 & 0.312 & 7.56 & 0.013 & 0.52 & -0.008 & -0.19 & 0.002 & 0.42 & $35.82 \%$ & 4842 \\
\hline $05-06$ & 0.031 & 7.69 & 0.305 & 7.67 & -0.004 & 0.13 & 0.006 & 0.03 & 0.004 & 0.91 & $33.93 \%$ & 4859 \\
\hline 06-07 & 0.027 & 7.28 & 0.339 & 8.81 & -0.015 & -0.28 & 0.020 & 0.41 & 0.007 & 2.15 & $37.04 \%$ & 4822 \\
\hline $07-08$ & 0.029 & 7.58 & 0.316 & 9.20 & -0.013 & -0.95 & 0.022 & 1.30 & 0.008 & 2.28 & $34.28 \%$ & 4262 \\
\hline 08-09 & 0.034 & 9.50 & 0.276 & 8.49 & 0.002 & 0.14 & 0.006 & 0.23 & 0.007 & 2.03 & $33.00 \%$ & 4123 \\
\hline Average & 0.032 & 6.94 & 0.321 & 7.47 & 0.003 & 0.24 & 0.021 & 0.94 & 0.011 & 2.46 & $38.56 \%$ & 3545 \\
\hline Stdev & 0.006 & 1.18 & 0.045 & 1.03 & 0.016 & 0.54 & 0.017 & 0.70 & 0.006 & 1.14 & $6.72 \%$ & 1034 \\
\hline Minimum & 0.019 & 4.75 & 0.264 & 5.99 & -0.024 & -0.95 & -0.012 & -0.19 & 0.001 & 0.18 & $30.68 \%$ & 1682 \\
\hline Q1 & 0.027 & 6.20 & 0.287 & 6.71 & -0.008 & -0.11 & 0.009 & 0.46 & 0.008 & 2.06 & $33.49 \%$ & 2587 \\
\hline Median & 0.031 & 6.80 & 0.314 & 7.23 & 0.002 & 0.25 & 0.021 & 0.87 & 0.012 & 2.68 & $36.73 \%$ & 3910 \\
\hline Q3 & 0.034 & 7.58 & 0.343 & 7.87 & 0.012 & 0.58 & 0.034 & 1.38 & 0.015 & 3.24 & $40.60 \%$ & 4423 \\
\hline Maximum & 0.046 & 9.54 & 0.469 & 10.35 & 0.043 & 1.43 & 0.049 & 2.65 & 0.022 & 4.57 & $54.06 \%$ & 4859 \\
\hline \multicolumn{13}{|c|}{ Panel B: by industry, mean value for 30-year } \\
\hline Industry & $\delta_{1}$ & t-stat & $\delta_{2}$ & t-stat & $\delta_{3}$ & t-stat & $\delta_{4}$ & t-stat & $\delta_{5}$ & t-stat & $\operatorname{adj}-R^{2}$ & $\mathrm{~N}$ \\
\hline 1 & 0.034 & 8.25 & 0.279 & 6.74 & 0.015 & 0.80 & 0.008 & 0.45 & 0.016 & 3.99 & $40.09 \%$ & 20985 \\
\hline 2 & 0.040 & 8.34 & 0.299 & 8.57 & 0.002 & 0.07 & 0.018 & 1.21 & 0.010 & 2.01 & $36.30 \%$ & 26202 \\
\hline 3 & 0.032 & 8.22 & 0.267 & 7.56 & -0.001 & -0.04 & 0.022 & 1.04 & 0.010 & 2.45 & $34.54 \%$ & 19917 \\
\hline 4 & 0.015 & 1.66 & 0.454 & 5.78 & -0.007 & -0.15 & 0.039 & 0.89 & 0.007 & 0.77 & $43.68 \%$ & 7818 \\
\hline 5 & 0.037 & 8.21 & 0.307 & 8.69 & 0.005 & 0.54 & 0.018 & 1.11 & 0.014 & 3.08 & $38.20 \%$ & 31440 \\
\hline Average & 0.032 & 6.94 & 0.321 & 7.47 & 0.003 & 0.24 & 0.021 & 0.94 & 0.011 & 2.46 & $38.56 \%$ & 21272 \\
\hline
\end{tabular}


Table 3

Implied Cost of Capital, Growth Rate, Valuation Multiples, and Risk Premium

Table 3 reports the implied long term average cost of capital, growth rate, valuation multiples and the risk premium for each of the 150 industry-year portfolios for 5-industry over 1980-2009. Industry classification is per Ken French's website. Growth rate, implied cost of capital, valuation multiples and conservatism parameter are: $g=\frac{1+\delta_{2}+\delta_{3}-\delta_{5}+\sqrt{\left(1+\delta_{2}+\delta_{3}-\delta_{5}\right)^{2}-4\left(\delta_{2}-\delta_{4}-\delta_{5}\right)}}{2}-1, R-1=(1+g)\left(1+\frac{\delta_{1}+\delta_{5}}{1+g-\delta_{2}}\right)-1$,

$\beta_{1}=\frac{(R-1) \delta_{2}+\delta_{4}+\delta_{5}}{(1+g)\left(1+g-\delta_{2}\right)}, \beta_{2}=\frac{\delta_{2}-\left(\delta_{4}+\delta_{5}\right)}{R\left(1+g-\delta_{2}\right)}, \lambda=\frac{(1+g) \delta_{5}}{1+g-\delta_{2}}$ respectively, where $\delta_{\mathrm{i}}(\mathrm{i}=1-5)$ are from regression: $\frac{\text { feps }_{t+1}}{P_{t}}=\delta_{1}+\delta_{2} \frac{x_{t}}{P_{t}}+\delta_{3} \frac{b_{t}}{P_{t}}+\delta_{4} \frac{b_{t-1}}{P_{t}}+\delta_{5} \frac{P_{t-1}}{P_{t}}+\varepsilon_{t+1}$, over a two-year rolling window. The risk premium (RP) is calculated relative to the yield on a 10 -year US government bond. feps $s_{t+1}$ is the median consensus forecasts of earnings at the first month after the corresponding I/B/E/S-reported prior-year earnings announcements; $P_{t}$ and $P_{t-1}$ are the contemporary equity price and lagged equity price respectively; $b_{t}$ and $b_{t-1}$ are the contemporary book value of equity and lagged book value of equity respectively; $x_{t}$ is net income before extraordinary items. The descriptive statistics are also reported. Panels A and B report the results on a year-by-year basis and industry-byindustry basis respectively.

\begin{tabular}{|c|c|c|c|c|c|c|}
\hline year & $(\mathrm{R}-1)(\%)$ & $\mathrm{g}(\%)$ & $\beta_{1}$ & $\beta_{2}$ & $\lambda$ & $\mathrm{RP}(\%)$ \\
\hline $79-80$ & 14.710 & 2.190 & 0.157 & 0.722 & 0.037 & 3.283 \\
\hline $80-81$ & 14.400 & 4.374 & 0.134 & 0.529 & 0.026 & 0.477 \\
\hline $81-82$ & 13.340 & 3.979 & 0.141 & 0.419 & 0.030 & 0.329 \\
\hline $82-83$ & 12.960 & 5.309 & 0.091 & 0.521 & 0.029 & 1.856 \\
\hline 83-84 & 12.080 & 4.605 & 0.053 & 0.503 & 0.022 & -0.385 \\
\hline $84-85$ & 10.780 & 2.901 & 0.115 & 0.401 & 0.022 & 0.165 \\
\hline $85-86$ & 9.833 & 3.180 & 0.112 & 0.297 & 0.015 & 2.163 \\
\hline $86-87$ & 10.280 & 3.908 & 0.103 & 0.279 & 0.020 & 1.886 \\
\hline $87-88$ & 11.190 & 4.246 & 0.109 & 0.317 & 0.015 & 2.341 \\
\hline 88-89 & 11.340 & 4.525 & 0.075 & 0.307 & 0.026 & 2.850 \\
\hline 89-90 & 11.140 & 4.496 & 0.083 & 0.295 & 0.031 & 2.595 \\
\hline $90-91$ & 10.520 & 4.292 & 0.091 & 0.306 & 0.023 & 2.657 \\
\hline $91-92$ & 9.643 & 4.091 & 0.065 & 0.310 & 0.006 & 2.633 \\
\hline $92-93$ & 9.355 & 3.317 & 0.115 & 0.453 & 0.018 & 3.485 \\
\hline 93-94 & 10.160 & 4.367 & 0.106 & 0.400 & 0.020 & 3.075 \\
\hline $94-95$ & 10.330 & 4.887 & 0.062 & 0.324 & 0.018 & 3.756 \\
\hline $95-96$ & 9.570 & 4.444 & 0.064 & 0.289 & 0.017 & 3.130 \\
\hline $96-97$ & 9.202 & 4.660 & 0.087 & 0.262 & 0.014 & 2.852 \\
\hline $97-98$ & 8.796 & 3.945 & 0.113 & 0.351 & 0.018 & 3.536 \\
\hline 98-99 & 9.359 & 4.135 & 0.137 & 0.435 & 0.024 & 3.709 \\
\hline 99-00 & 9.620 & 4.288 & 0.131 & 0.379 & 0.017 & 3.590 \\
\hline 00-01 & 8.166 & 3.682 & 0.065 & 0.346 & 0.001 & 3.146 \\
\hline 01-02 & 7.451 & 2.815 & 0.040 & 0.366 & 0.000 & 2.841 \\
\hline 02-03 & 7.089 & 2.182 & 0.076 & 0.484 & 0.011 & 3.079 \\
\hline 03-04 & 5.795 & 0.993 & 0.033 & 0.582 & 0.002 & 1.525 \\
\hline $04-05$ & 5.426 & 0.557 & 0.013 & 0.477 & 0.004 & 1.136 \\
\hline
\end{tabular}




\begin{tabular}{ccccccc}
$05-06$ & 5.090 & 0.178 & 0.038 & 0.440 & 0.005 & 0.290 \\
$06-07$ & 5.855 & 0.844 & 0.076 & 0.456 & 0.010 & 1.225 \\
$07-08$ & 6.590 & 1.409 & 0.071 & 0.391 & 0.012 & 2.930 \\
$08-09$ & 6.706 & 1.285 & 0.042 & 0.347 & 0.009 & 3.446 \\
& & & & & & \\
Average & 9.559 & 3.336 & 0.087 & 0.400 & 0.017 & 2.320 \\
Stdev & 2.557 & 1.454 & 0.036 & 0.104 & 0.009 & 1.199 \\
FM-t statis & 20.473 & 12.566 & 13.228 & 20.969 & 9.653 & 10.594 \\
Q1 & 7.630 & 2.346 & 0.064 & 0.312 & 0.011 & 1.608 \\
Median & 9.632 & 3.962 & 0.085 & 0.385 & 0.017 & 2.749 \\
Q3 & 11.050 & 4.372 & 0.113 & 0.455 & 0.023 & 3.142 \\
\hline
\end{tabular}

Panel B: by industry, mean value for 30-year

\begin{tabular}{ccccccc} 
Industry & $(\mathrm{R}-1)(\%)$ & $\mathrm{g}(\%)$ & $\beta_{1}$ & $\beta_{2}$ & $\lambda$ & $\mathrm{RP}(\%)$ \\
\hline 1 & 10.030 & 3.032 & 0.067 & 0.318 & 0.023 & 2.786 \\
2 & 9.827 & 2.758 & 0.076 & 0.347 & 0.014 & 2.588 \\
3 & 8.445 & 2.676 & 0.067 & 0.290 & 0.014 & 1.206 \\
4 & 8.905 & 5.012 & 0.135 & 0.687 & 0.013 & 1.666 \\
5 & 10.590 & 3.203 & 0.088 & 0.357 & 0.020 & 3.355 \\
Average & 9.559 & 3.336 & 0.087 & 0.400 & 0.017 & 2.320 \\
\hline
\end{tabular}




\section{Table 4. \\ Excess Realized Return, Implied Risk Premium and Risk Proxies}

Panel A of this table reports descriptive statistics of excess realized return, estimated risk premium and risk proxies over 1980-2009. Annual realized returns are calculated by compounding 12-monthly returns from April of year $t$ to March of year $t+1$. XRET1 is excess one-year-ahead realized returns over the yields of 10-year US government bond. ERP is expected risk premium, which is equal to the difference between the implied expected return (IER) and 10-year US government bond yields. CFN equals actual earnings per share for year $\mathrm{t}+1$ less analysts' forecasts of one-year-ahead earnings per share, scaled by stock price at time t. DRN is proxied by $\left(I E R_{i, t}-I E R_{i, t-1}\right)$. Term (spread) is calculated as the difference between 10-Year US Treasury constant maturity rate and the 3-Month US T-Bill yields. Default (spread) is calculated as the difference between Moody's Seasoned Baa and Aaa Corporate Bond yields. Data on corporate bonds and US T-Bills/Bonds are obtained from the FRED database of the Federal Reserve Bank of St. Louis. Size is the logarithm of a firm's market capitalization. Lev is total debt divided by the firm's market capitalization as of 3-month after the fiscal year end. Beta is estimated via the market model using the value weighted NYSE/Amex market index return using at least 18 and up to 60 months of lagged monthly returns. Panel B shows the Pearson correlations for 43,674 firm-year observations. Unexp.Ret $=$ XRET1 - ERP. Panel C reports one-year ahead realized returns for IER quintile sorted portfolio, as well as the average return spread between quintiles 5 and 1.

Panel A: Descriptive Statistics

\begin{tabular}{|c|c|c|c|c|c|c|c|c|c|}
\hline & XRET1 & ERP & CFN & DRN & Beta & Size & Lev & Term & Default \\
\hline $\mathrm{N}$ & 43674 & 45022 & 44698 & 39012 & 43846 & 45022 & 44702 & 45022 & 45022 \\
\hline Mean & 0.111 & 0.047 & -0.044 & -0.012 & 1.058 & 6.014 & 0.699 & 1.685 & 1.095 \\
\hline Stdev & 0.602 & 0.047 & 0.156 & 0.069 & 0.610 & 1.723 & 1.922 & 1.373 & 0.582 \\
\hline $5 \%$ & -0.582 & 0.005 & -0.224 & -0.106 & 0.213 & 3.360 & 0.000 & -0.530 & 0.640 \\
\hline Q1 & -0.213 & 0.019 & -0.029 & -0.023 & 0.614 & 4.753 & 0.060 & 0.580 & 0.690 \\
\hline Median & 0.036 & 0.035 & -0.003 & -0.005 & 0.984 & 5.924 & 0.260 & 1.580 & 0.960 \\
\hline Q3 & 0.312 & 0.058 & 0.004 & 0.010 & 1.395 & 7.182 & 0.714 & 2.840 & 1.180 \\
\hline $95 \%$ & 1.008 & 0.135 & 0.025 & 0.054 & 2.202 & 9.061 & 2.547 & 3.540 & 2.320 \\
\hline \multicolumn{10}{|c|}{ Panel B: Correlation } \\
\hline & XRET1 & Unexp.Ret & CFN & DRN & Beta & Size & Lev & Term & Default \\
\hline XRET1 & 1 & & & & & & & & \\
\hline Unexp.Ret & 0.139 & 1 & & & & & & & \\
\hline CFN & 0.194 & 0.216 & 1 & & & & & & \\
\hline DRN & -0.159 & -0.126 & 0.101 & 1 & & & & & \\
\hline Beta & 0.016 & 0.012 & -0.086 & -0.063 & 1 & & & & \\
\hline Size & -0.053 & -0.036 & 0.236 & 0.107 & -0.054 & 1 & & & \\
\hline Lev & 0.057 & 0.041 & -0.158 & -0.103 & -0.030 & -0.074 & 1 & & \\
\hline Term & 0.113 & 0.112 & 0.045 & -0.034 & -0.005 & 0.016 & 0.003 & 1 & \\
\hline Default & 0.165 & 0.155 & -0.032 & -0.110 & 0.045 & -0.025 & 0.083 & 0.165 & 1 \\
\hline \multicolumn{10}{|c|}{ Panel C: Returns on IER-sorted portfolios } \\
\hline \multicolumn{3}{|c|}{ IER quintiles } & 1 & 2 & & 3 & 4 & 5 & Q5-Q1 \\
\hline \multicolumn{3}{|c|}{ Mean of IER } & 0.073 & 0.087 & & 99 & 0.116 & 0.179 & 0.107 \\
\hline \multicolumn{3}{|c|}{$\begin{array}{l}\text { Mean of 12-month ahead realized } \\
\text { returns }\end{array}$} & 0.087 & 0.088 & & 96 & 0.111 & 0.174 & 0.087 \\
\hline \multicolumn{3}{|c|}{$\begin{array}{l}\text { Mean of 60-month ahead realized } \\
\text { returns }\end{array}$} & 0.750 & 0.796 & & 310 & 0.899 & 1.216 & 0.466 \\
\hline
\end{tabular}




\section{Table 5}

\section{Regressing Excess One-year-ahead Realized Returns on the Implied Risk Premium and Risk Proxies}

Table 5 presents regression coefficients (t-values) of excess one-year-ahead realized returns (XRET1) on expected risk premium (ERP) and risk proxies. Two-way cluster-robust standard errors are used to correct for both cross-sectional and time-series dependence. Risk-free rate is proxied by 10-year US government bond yields. CFN equals actual earnings per share for year $t+1$ less analysts' forecasts of one-year-ahead earnings per share, scaled by stock price at time t. DRN is proxied by $\left(I E R_{i, t}-I E R_{i, t-1}\right)$. Term (spread) is calculated as the difference between 10-Year US Treasury constant maturity rate and the 3-Month US T-Bill yields. Default (spread) is calculated as the difference between Moody's Seasoned Baa and Aaa Corporate Bond yields. Size is the logarithm of a firm's market capitalization. Lev is total debt divided by the firm's market capitalization as of 3month after the fiscal year end. Beta is estimated via the market model using the value weighted NYSE/Amex market index return using at least 18 and up to 60 months of lagged monthly returns. $\mathrm{B} / \mathrm{P}$ is ratio of book-to-market.

\begin{tabular}{|c|c|c|c|c|c|c|}
\hline & XRET1 & XRET1 & XRET1 & XRET1 & XRET1 & XRET1 \\
\hline \multirow{2}{*}{ ERP } & 1.83 & 2.15 & 1.86 & 1.61 & 1.55 & 1.51 \\
\hline & $(2.62)$ & (3.66) & (3.09) & $(3.16)$ & $(3.52)$ & (4.6) \\
\hline \multirow{2}{*}{$\mathrm{CFN}$} & & 1.23 & 1.33 & 1.38 & & 1.35 \\
\hline & & (12.77) & (12.27) & (12.16) & & (12.68) \\
\hline \multirow[t]{2}{*}{ DRN } & & -0.959 & -0.93 & -0.857 & & -0.794 \\
\hline & & $(-4.66)$ & $(-4.89)$ & $(-4.54)$ & & $(-4.34)$ \\
\hline \multirow[t]{2}{*}{ Beta } & & & 0.018 & 0.022 & & 0.018 \\
\hline & & & $(0.44)$ & $(0.54)$ & & $(0.46)$ \\
\hline \multirow[t]{2}{*}{ Size } & & & -0.029 & -0.021 & & -0.022 \\
\hline & & & $(-2.75)$ & $(-1.82)$ & & $(-2.15)$ \\
\hline \multirow[t]{2}{*}{ Lev } & & & 0.015 & 0.005 & & \\
\hline & & & $(2.81)$ & $(1.45)$ & & \\
\hline \multirow[t]{2}{*}{$\mathrm{B} / \mathrm{P}$} & & & & 0.109 & & 0.089 \\
\hline & & & & $(2.51)$ & & $(3.42)$ \\
\hline \multirow[t]{2}{*}{ Term } & & & & & 0.039 & 0.034 \\
\hline & & & & & (1.28) & (1.04) \\
\hline \multirow[t]{2}{*}{ Default } & & & & & 0.137 & 0.12 \\
\hline & & & & & (1.95) & $(1.75)$ \\
\hline \multirow[t]{2}{*}{ Constant } & 0.026 & 0.038 & 0.201 & 0.103 & -0.178 & -0.054 \\
\hline & $(0.62)$ & $(0.9)$ & $(2.35)$ & $(0.92)$ & $(-1.71)$ & $(-0.37)$ \\
\hline $\operatorname{adj}-R^{2}$ & $1.93 \%$ & $8.02 \%$ & $8.75 \%$ & $9.53 \%$ & $4.83 \%$ & $11.70 \%$ \\
\hline
\end{tabular}




\section{Table 6}

\section{Relation Between Implied Risk Premium and Risk Proxies}

This table presents regression coefficients (t-values) of expected risk premium (ERP) on various risk proxies. Two-way cluster-robust standard errors are used to correct for both cross-sectional and time-series dependence. Risk-free rate is proxied by 10 -year US government bond yields. Term (spread) is calculated as the difference between 10-Year US Treasury constant maturity rate and the 3-Month US T-Bill yields. Default (spread) is calculated as the difference between Moody's Seasoned Baa and Aaa Corporate Bond yields. Size is the logarithm of a firm's market capitalization. Lev is total debt dividend by the firm's market capitalization as of 3-months after the fiscal year end. Beta is estimated via the market model using the value weighted NYSE/Amex market index return using at least 18 and up to 60 months of lagged monthly returns. Stdev is the standard deviation of annual stock returns.

\begin{tabular}{|c|c|c|c|c|c|c|}
\hline Beta & $\begin{array}{l}0.005 \\
(2.67)\end{array}$ & & & $\begin{array}{l}0.004 \\
(2.64)\end{array}$ & $\begin{array}{l}0.004 \\
(2.44)\end{array}$ & $\begin{array}{l}-0.003 \\
(-1.41)\end{array}$ \\
\hline Size & & $\begin{array}{c}-0.007 \\
(-12.39)\end{array}$ & & & $\begin{array}{l}-0.006 \\
(-11.37)\end{array}$ & $\begin{array}{l}-0.005 \\
(-9.46)\end{array}$ \\
\hline Lev & & & $\begin{array}{l}0.006 \\
(7.48)\end{array}$ & & $\begin{array}{l}0.005 \\
(7.51)\end{array}$ & $\begin{array}{l}0.005 \\
(7.57)\end{array}$ \\
\hline Term & & & & $\begin{array}{l}0.000 \\
(-0.3)\end{array}$ & $\begin{array}{c}0.000 \\
(-0.13)\end{array}$ & \\
\hline Default & & & & $\begin{array}{l}0.012 \\
(5.37)\end{array}$ & $\begin{array}{l}0.010 \\
(3.05)\end{array}$ & \\
\hline Stdev & & & & & & $\begin{array}{l}0.046 \\
(6.24)\end{array}$ \\
\hline Constant & $\begin{array}{c}0.043 \\
(19.59)\end{array}$ & $\begin{array}{c}0.088 \\
(19.08)\end{array}$ & $\begin{array}{c}0.043 \\
(21.73)\end{array}$ & $\begin{array}{l}0.031 \\
(5.67)\end{array}$ & $\begin{array}{l}0.067 \\
(9.77)\end{array}$ & $\begin{array}{c}0.057 \\
(11.45)\end{array}$ \\
\hline $\operatorname{adj}-R^{2}$ & $0.34 \%$ & $5.94 \%$ & $5.12 \%$ & $2.35 \%$ & $11.90 \%$ & $12.10 \%$ \\
\hline
\end{tabular}


Table 7

Regressing Excess One-year-ahead Realized Returns on the Implied Risk Premium and Risk Proxies Using Size Sorting

Table 7 presents regression coefficients (t-values) of excess one-year-ahead realized returns (XRET1) on expected risk premium (ERP) and risk proxies by sorting firms in each industry-year-size portfolio. Two-way cluster-robust standard errors are used to correct for both cross-sectional and time-series dependence. Risk-free rate is proxied by 10-year US government bond yields. CFN equals actual earnings per share for year $\mathrm{t}+1$ less analysts' forecasts of one-year ahead earnings per share, scaled by stock price at time t. DRN is proxied by $\left(I E R_{i, t}-I E R_{i, t-1}\right)$. Term (spread) is calculated as the difference between 10-Year US Treasury constant maturity rate and the 3-Month US T-Bill yields. Default (spread) is calculated as the difference between Moody's Seasoned Baa and Aaa Corporate Bond yields. Size is the logarithm of a firm's market capitalization. Lev is total debt dividend by the firm's market capitalization as of 3-months after the fiscal year end. Beta is estimated via the market model using the value weighted NYSE/Amex market index return using at least 18 and up to 60 months of lagged monthly returns. $\mathrm{B} / \mathrm{P}$ is the book-to-market ratio.

\begin{tabular}{|c|c|c|c|c|c|c|}
\hline & XRET1 & XRET1 & XRET1 & XRET1 & XRET1 & XRET1 \\
\hline ERP & $\begin{array}{c}1.74 \\
(2.59)\end{array}$ & $\begin{array}{c}2.06 \\
(3.36)\end{array}$ & $\begin{array}{c}1.84 \\
(3.03)\end{array}$ & $\begin{array}{c}1.65 \\
(3.04)\end{array}$ & $\begin{array}{c}1.47 \\
(3.32)\end{array}$ & $\begin{array}{c}1.5 \\
(4.14)\end{array}$ \\
\hline CFN & & $\begin{array}{c}1.18 \\
(11.95)\end{array}$ & $\begin{array}{c}1.29 \\
(11.65)\end{array}$ & $\begin{array}{c}1.34 \\
(11.76)\end{array}$ & & $\begin{array}{c}1.31 \\
(12.05)\end{array}$ \\
\hline DRN & & $\begin{array}{c}-0.697 \\
(-3.6)\end{array}$ & $\begin{array}{l}-0.649 \\
(-3.62)\end{array}$ & $\begin{array}{l}-0.558 \\
(-3.06)\end{array}$ & & $\begin{array}{l}-0.535 \\
(-3.01)\end{array}$ \\
\hline Beta & & & $\begin{array}{c}0.016 \\
(0.4)\end{array}$ & $\begin{array}{c}0.021 \\
(0.5)\end{array}$ & & $\begin{array}{l}0.015 \\
(0.38)\end{array}$ \\
\hline Size & & & $\begin{array}{l}-0.033 \\
(-3.21)\end{array}$ & $\begin{array}{l}-0.026 \\
(-2.15)\end{array}$ & & $\begin{array}{l}-0.026 \\
(-2.45)\end{array}$ \\
\hline Lev & & & $\begin{array}{c}0.014 \\
(2.4)\end{array}$ & $\begin{array}{l}0.002 \\
(0.59)\end{array}$ & & \\
\hline $\mathrm{B} / \mathrm{P}$ & & & & $\begin{array}{l}0.101 \\
(2.43)\end{array}$ & & $\begin{array}{l}0.083 \\
(3.13)\end{array}$ \\
\hline Term & & & & & $\begin{array}{l}0.038 \\
(1.26)\end{array}$ & $\begin{array}{l}0.034 \\
(1.02)\end{array}$ \\
\hline Default & & & & & $\begin{array}{l}0.138 \\
(1.92)\end{array}$ & $\begin{array}{l}0.125 \\
(1.76)\end{array}$ \\
\hline Constant & $\begin{array}{l}0.022 \\
(0.54)\end{array}$ & $\begin{array}{l}0.034 \\
(0.81)\end{array}$ & $\begin{array}{l}0.226 \\
(2.67)\end{array}$ & $\begin{array}{l}0.130 \\
(1.15)\end{array}$ & $\begin{array}{c}-0.182 \\
(-1.7)\end{array}$ & $\begin{array}{l}-0.035 \\
(-0.24)\end{array}$ \\
\hline adj-R ${ }^{2}$ & $1.96 \%$ & $7.43 \%$ & $8.32 \%$ & $9.12 \%$ & $4.84 \%$ & $11.40 \%$ \\
\hline
\end{tabular}




\section{Table 8}

\section{Relation Between Implied Risk Premium and Risk Proxies Using Size Sorting}

This table presents regression coefficients (t-values) of expected risk premium (ERP) on various risk proxies by sorting firms in each industry-year-size portfolio. Two-way cluster-robust standard errors are used to correct for both cross-sectional and time-series dependence. Risk-free rate is proxied by 10-year US government bond yields. Term (spread) is calculated as the difference between 10-Year US Treasury constant maturity rate and the 3-Month US T-Bill yields. Default (spread) is calculated as the difference between Moody's Seasoned Baa and Aaa Corporate Bond yields. Size is the logarithm of a firm's market capitalization. Lev is total debt dividend by the firm's market capitalization as of 3-months after the fiscal year end. Beta is estimated via the market model using the value weighted NYSE/Amex market index return using at least 18 and up to 60 months of lagged monthly returns. Stdev is the standard deviation of annual stock returns.

\begin{tabular}{|c|c|c|c|c|c|c|}
\hline Beta & $\begin{array}{l}0.006 \\
(2.84)\end{array}$ & & & $\begin{array}{l}0.005 \\
(2.78)\end{array}$ & $\begin{array}{l}0.005 \\
(2.71)\end{array}$ & $\begin{array}{l}-0.002 \\
(-0.93)\end{array}$ \\
\hline Size & & $\begin{array}{l}-0.006 \\
(-8.11)\end{array}$ & & & $\begin{array}{l}-0.005 \\
(-7.34)\end{array}$ & $\begin{array}{c}-0.004 \\
(-5.9)\end{array}$ \\
\hline Lev & & & $\begin{array}{l}0.005 \\
(6.05)\end{array}$ & & $\begin{array}{l}0.004 \\
(6.29)\end{array}$ & $\begin{array}{l}0.005 \\
(6.13)\end{array}$ \\
\hline Term & & & & $\begin{array}{c}0.000 \\
(0.1)\end{array}$ & $\begin{array}{l}0.000 \\
(0.34)\end{array}$ & \\
\hline Default & & & & $\begin{array}{c}0.012 \\
(5.9)\end{array}$ & $\begin{array}{c}0.010 \\
(3.6)\end{array}$ & \\
\hline Stdev & & & & & & $\begin{array}{c}0.0462 \\
(6.15)\end{array}$ \\
\hline Constant & $\begin{array}{l}0.045 \\
(23.7)\end{array}$ & $\begin{array}{c}0.086 \\
(14.66)\end{array}$ & $\begin{array}{c}0.047 \\
(26.05)\end{array}$ & $\begin{array}{l}0.033 \\
(6.65)\end{array}$ & $\begin{array}{c}0.062 \\
(10.25)\end{array}$ & $\begin{array}{l}0.054 \\
(9.73)\end{array}$ \\
\hline $\operatorname{adj}-R^{2}$ & $0.45 \%$ & $3.90 \%$ & $4.29 \%$ & $2.33 \%$ & $9.36 \%$ & $9.35 \%$ \\
\hline
\end{tabular}

